\title{
EFFECTS OF SOME PLANT EXTRACTS ON THE GROWTH PERFORMANCE AND NUTRIENT UTILIZATION OF FRESH WATER PRAWN, M. ROSENBERGII, POST LARVA.
}

\author{
Khalid A. El-Damhogy ${ }^{1}$, mohammed A. A. Zaki ${ }^{2}$, Atef A. A. El-Hela ${ }^{3}$, Amr M. Nasef ${ }^{1}$ \\ and Ahmed N. Al-Abssawy ${ }^{1}$ \\ 1 Marine Biology and Fishes Sector, Zoology Department, Faculty of Science, Al-Azhar \\ University, Cairo. \\ 2 Fish Nutritional and Husbandry and head of Animal Production Department, Faculty of \\ Agriculture (Shatby), Alexandria University. \\ 3 Pharmacognosy Department, Faculty of Pharmacy, Al-Azhar University, Cairo.
}

\begin{abstract}
:
In order to study the effects of some plant extracts on Macrobrachium rosenbergii cultivated in fiber tanks, freshwater prawns were randomly divided into eight groups: a control group was fed with basal diet, and seven treatment groups in two replicates fed with basal diet supplemented with $0.05 \%$, of peanuts, Arachis Hypogaea (A), $0.05 \%$ of sesames, Sesamum Indicum (B) and $0.05 \%$ of sun flower seeds, Helianthus Annuus (C) also using mixture from them under the same proportion as (AB), (AC), (BC) and (ABC) extracts for 12 weeks, respectively. experiment were conducted on fresh water prawns Macrobrachium rosenbergii post larvae (PL) with an average initial body weight $0.09 \pm 0.01^{\mathrm{a}} \mathrm{g}$ was obtained from Fish Hatchery, Mariut fish farm Company, Alexandria Governorate, Egypt. Water quality parameters, temperature, salinity, dissolved oxygen, $\mathrm{pH}$, ammonia, nitrate and nitrite were monitored. The experiment lasted 84 days and biomass gain was evaluated every two weeks. Final biomass, survival rate and feed conversion rates were calculated at the end of the experiment. Results revealed that, The final weight obtained by the prawn fed diets contained (B), $(\mathrm{AB})$ and $(\mathrm{A})$ extracts is significantly at $(\mathrm{P}<0.05)$ higher than the fish fed the same diets with other extracts as $(\mathrm{ABC}),(\mathrm{AC}),(\mathrm{C})$ and $(\mathrm{BC})$; being $8.13 \pm 0.24,7.55 \pm 0.21$ and $7.31 \pm$ 0.15 respectively in the formers and $6.76 \pm 0.23,5.43 \pm 0.22,4.75 \pm 0.12$ and $4.23 \pm 0.07$ respectively in the latter's against control as $3.62 \pm 0.04$. In general, the maximum value $(8.13$ \pm 0.24 ) was recorded in the prawn fed with diet contained extract (B) and the minimum value $(4.23 \pm 0.07)$ occurred in the prawn fed with diet contained extract $(\mathrm{BC})$. The highest protein intake was obtained by the diet with (B) and (A) extracts and the lowest in the diet of (BC) extract; the proportions being $9.48 \pm 0.04^{\mathrm{a}}$ and $9.38 \pm 0.18^{\mathrm{a}}$ in the former and $7.22 \pm 0.08$ in the latter. The highest feed conversion ratio was obtained by the diet with (BC) and (C) extracts and the lowest in the diet of $(\mathrm{B})$ extract; the proportions being $3.90 \pm 0.10^{\mathrm{ab}}$ and 3.66 $\pm 0.08^{\mathrm{b}}$ in the former and $2.62 \pm 0.06$ in the latter.
\end{abstract}

Key Words: peanuts, Macrobrachium rosenbergii, growth performance, Final biomass.

\section{INTRODUCTION}

The giant freshwater prawn, Macrobrachium rosenbergii (De Man, 1879), is a commercially important aquaculture species. Its culture has expanded rapidly not only within Asia but also in regions far remote from the natural distribution of the species (FAO, 2000). Considering that antibiotics should no longer be used as animal growth promoters, there is currently a significant interest in short chain fatty acids (SCFAs) as biocontrol agents in animal production (Defoirdt et al., 2006). Several studies have shown that SCFAs inhibit the 
growth of yeasts and entero bacteria such as Salmonella typhimurium, Escherichia coli and Shigella flexneri (Cherrington et al., 1991; Bearson et al., 1997; Sun et al., 1998; Van Immerseel et al., 2003). SCFAs have previously been shown to inhibit or decrease the growth of Salmonella in chickens (Waldroup et al., 1995; Van Der Wielen et al., 2000; Van Immerseel $\boldsymbol{e t}$ al., 2005) and of pathogenic luminescent Vibrios in in vitro tests (Defoirdt $\boldsymbol{e t}$ al., 2006). Moreover, SCFAs were shown to significantly increase the survival of challenged brine shrimp (Artemia) nauplii. In addition, SCFAs might also provide with energy for shrimp (Defoirdt et al., 2006). Effective fatty acid concentrations are rather high and consequently, it would not be economically feasible to dose fatty acids in the culture water of an aquaculture system in order to protect the animals. Moreover, the addition of high levels of organic carbon in the water would give rise to an excessive growth of heterotrophic bacteria which might have a negative effect on the health of the animals (because of oxygen depletion and/or because the growing bacteria could be pathogenic).

Conversely, some of the factors which limit incorporation of plant oil seeds and their by-products at high levels within aquafeeds for warm water omnivorous/herbivorous fish species (Lim and Dominy, 1991) are low protein contents, amino-acid imbalance and presence of anti-nutritional factors (Wee, 1991). However, the seed contains up to $50 \mu \mathrm{g} / \mathrm{g}$ phytic acid (PA) anti-nutritional factor which reduces the biological availability of zinc, calcium, magnesium and iron (Nahm, 2007) that inhibiting the absorption of these important minerals (Gobi, 1981). Diarra and Usman (2008) reported that soaking is one of the most effective methods of lowering the phytic acid (PA) content of the seed. Lipids for the freshwater prawn Macrobrachium rosenbergii supply essential fatty acids needed for the maintenance and integrity of cellular membranes, and serve as precursors of steroid and molting hormones (Teshima, 1972; Harrison, 1990).

\section{MATERIAL AND METHODS}

Experiments was designed to investigate the effect of eight different diets on growth performance and feed utilization of freshwater prawns $M$. rosenbergii post larvae (PL) reared in fiberglass tanks in monoculture culture system, 16 fiberglass tanks in each experiment with a capacity of $250 \mathrm{~L}$ were stocked with prawns PL at stable stocking densities (80 PL /250 L) in Animal and Fish Production Department, Faculty of Agriculture (EL-shatby), Alexandria University, Egypt. Two replicate were randomly assigned to each treatment. The fiberglass tanks were filled with de chlorinated tap water. Water was continuously aerated to supply oxygen. Each fiberglass tanks were provided with four $30 \mathrm{~cm}$ long $16 \mathrm{~mm}$ diameter black polyvinyl chloride (PVC) pipe to minimize the cannibalism during the molting as suggested by Mariappan \& Balasundaram (2004). The fiberglass tanks were cleaned daily from faeces and replacing two-thread of the water. Prawn PL was maintained on an artificial light photoperiod (12:12 h light: dark schedule). Mortality and limb less were recorded at $08.00 \mathrm{~h}$, once a day in first experiment, but in second experiment with out any artificial light.

The laboratory experiment was designed to determine the influence of eight different diets contain control with plant extract treatments as $0.05 \%$ of peanuts, Arachis Hypogaea (A), $0.05 \%$ of sesames, Sesamum Indicum (B) and $0.05 \%$ of sun flower seeds, Helianthus Annuus (C) also using mixture from us under the same proportion as $(\mathrm{AB}),(\mathrm{AC}),(\mathrm{BC})$ and $(\mathrm{ABC})$ as feed additive in order to study its effects on freshwater prawns $M$. rosenbergii (PL), performances and carcass composition were cultivated in fiberglass tanks for 84 days.

Prior to the start of experiment, the prawns PL were acclimated to the experimental conditions for two weeks. During this period, prawns PL was fed a fine minced tilapia flesh at 
a level of $20 \%$ of body weight. The daily ration was divided into three equal amounts and offered three times a day $(09.00,13.00$ and $17.00 \mathrm{~h}$ ). However, during the 84 days experimental period for each one, all freshwater prawn PL were fed their respective basal crumbles diet $45 \%$ CP showed in (Table 1). All prawn PL in each fiberglass tanks was collectively weighed every two week and the new feeding rate was re-adjusted based on estimated body weight, at a feeding rate of $20 \%$, decreasing $15 \%$ and decreasing $10 \%$ for each 30 days feeding thereafter, according to FAO (2002).

Dry ingredients were ground by screen diameter $(1.0 \mathrm{~mm})$ using a homogenous mixture grinder. Diets were processed by blending the dry ingredients for $15 \mathrm{~min}$, then mixing with oil and water. The mixture was passed through a laboratory hand pellet machine (locally made and dried for 48 hours $\left(2\right.$ days) at $60{ }^{\circ} \mathrm{C}$. Dried diets were passed through a 0.3 $\mathrm{mm}$ and stored at $-20^{\circ} \mathrm{C}$ until used.

\section{Extraction Teaqnique:}

Dried peanuts, Arachis Hypogaea (A), sesames, Sesamum Indicum (B) and sun flower seeds, Helianthus Annuus (C) seeds were ground in a Moulinex Model SeB PREP'LINE 850 (Moulinex coffee). For solvent extraction (soxlhet method), $50 \mathrm{~g}$ of ground seeds were placed into a cellulose paper cone and extracted using light petroleum ether (b.p $40-60^{\circ} \mathrm{C}$ ) in a 5-1 Soxhlet extractor for $8 \mathrm{~h}$ (Pena et al., 1992). The oil was then recovered by evaporating of the solvent using rotary evaporator Model N-1 (Eyela, Tokyo Rikakikal Co., Ltd., Japan) and residual solvent was removed by drying in an oven at $60^{\circ} \mathrm{C}$ for $1 \mathrm{~h}$ and flushing with $99.9 \%$ nitrogen.

\section{Instrumentation and chromatographic conditions:}

GC/MS System: SHIMADZU GC/MS-QP5050A.

SOFTWEAR: CLASS 5000.

SEARCHED LIBRARY: WILEY MASS SPECTRAL DATA BASE.

COLUMN; DBI; 30m; 0.53mm ID; $1.5 \mathrm{um}$ Film (J and W SCIENTIFIC).

CARRIER GAS: Helium.

IONIZATION MODE: EI.

IONIZATION VOLTAGE: 70ev.

TEMPERATURE PROGRAM: $115^{\circ} \mathrm{C}(1 \mathrm{~min})-200{ }^{\circ} \mathrm{C}(1 \mathrm{~min})$ at $10{ }^{\circ} \mathrm{C} / \mathrm{min}-240{ }^{\circ} \mathrm{C}(2 \mathrm{~min})$ at $5^{\circ} \mathrm{C} / \mathrm{min}-260^{\circ} \mathrm{C}(3 \mathrm{~min})$ at $3.5^{\circ} \mathrm{C} / \mathrm{min}$.

DETECTOR TEMPERATURE: $230^{\circ} \mathrm{C}$.

INJECTOR TEMPERATURE: $300^{\circ} \mathrm{C}$.

Antimicrobial activity:

Antimicrobial activity was determined using the agar well diffusion assay method as described by Holder and Boyce (1994). The tested organisms were sub cultured on nutrient agar medium (Oxoid laboratories, UK) for bacteria and Saboroud dextrose agar (Oxoid laboratories, UK) for fungi. PENICILLIN G and STREPTOMYCIN were used as a positive control for bacterial strains, Amphotericin B was used as a positive control for fungi. The plates were done in triplicate. Bacterial cultures were incubated at $37^{\circ} \mathrm{C}$ for $24 \mathrm{~h}$ while the other fungal cultures were incubated at $\left(25-30^{\circ} \mathrm{C}\right)$ for $3-7$ days Antimicrobial activity was determined by measurement zone of inhibition.

\section{Body composition analysis:}

At the start of the experiments, twenty fish and prawn were collected, immediately frozen and reserved for initial body proximate chemical analysis. At the end of each treatment, all fish and prawn in each aquarium were netted, weighed, frozen and kept for final body composition analysis. Fish samples were pulverized, and homogenized with Ultra-Tunax. The homogenized samples were oven dried at $60-80^{\circ} \mathrm{C}$ for $48 \mathrm{hrs}$. 
Proximate analyses of the whole body protein, lipid, and ash were performed according to standard methods described by AOAC (2000) as follows:

\section{Moisture content:}

To study moisture content, samples were dried in an oven adjusted at $105^{\circ} \mathrm{c}$ overnight and the loss in weight was reported as percentage of moisture.

\section{Crude protein (CP):}

Kjeldahl method was applied to determine total nitrogen content in feed and fish samples. The factor of 6.25 was used to estimate crude protein according to ISO, (1979).

\section{Ether extract (EE):}

To study ether extract Soxhelt apparatus operated with electric heater and provided with water condenser was utilized. Extraction of the fat contents has been carried out for 3 hours using petroleum ether as solvent according to Folch et al., (1956).

\section{Crude fibers (CF):}

Samples were treated with boiling in $\mathrm{H}_{2} \mathrm{SO}_{4}$ then $\mathrm{NaOH} 12.5 \%$ w/w for 10 minutes, each solution volume was kept constant by addition of boiling water. Final residues were washed by $5 \% \mathrm{HCL}$ to get rid of adhering $\mathrm{NaOH}$, then they filtered dried weight ashes at $550^{\circ} \mathrm{c}$ for 2 hours.

\section{Ash content:}

Ash contents were determined by incineration at $550^{\circ} \mathrm{c}$ in muffle furnace for 2 hours.

\section{Nitrogen free extract:} equation:

Nitrogen free extract in the experimental diets was calculated by using the following

$$
\mathrm{NFE}=100-(\text { Moisture }+\mathrm{CP}+\mathrm{EE}+\mathrm{CF})
$$

Where:

$$
\begin{aligned}
& \mathrm{NFE}=\text { Nitrogen free extract. } \\
& \mathrm{CP}=\text { Crude protein. } \\
& \mathrm{EE}=\text { Ether extract. } \\
& \mathrm{CF}=\text { Crude fiber. }
\end{aligned}
$$

\section{Gross energy (GE):}

Gross energy of diets was calculated according to the gross caloric values of NRC (1993) using the values of 5.64, 9.44 and $4.11 \mathrm{kcal} / \mathrm{g}$ diet crude protein, crude fat and total carbohydrate, respectively.

\section{Survival rate:}

Survival rate, expressed in percentage, was calculated based on the amount of harvested animals divided by the number of stocked individuals and multiplied by 100 .

Survival rate SR $(\%)=(\mathrm{n}$ end $/ \mathrm{n}$ initial $) \times 100$

\section{Measurement of growth:}

Total weight gain, average daily gain, specific growth rate, feed conversion ratio protein and energy utilization were determined according to Recker, (1975) and Castell and Tiews, (1980) as follow:

1- Total gain $(\mathrm{g} / \mathrm{fish})=\left(\mathrm{W}_{\mathrm{T}}-\mathrm{W}_{\mathrm{I}}\right)$.

Where:

$$
\mathrm{W}_{\mathrm{T}}=\text { Final means weight of fish in grams. }
$$


$\mathrm{W}_{\mathrm{I}}=$ Initial means weight of fish in grams.

2- Average daily gain $(\mathrm{ADG})(\mathrm{g} / \mathrm{fish} /$ day $)=$ total gain / duration period.

3- Specific growth rate $(\mathrm{SGR}) \% /$ day $)=100 \times\left(\mathrm{Ln} \mathrm{W}_{\mathrm{T}}-\mathrm{Ln} \mathrm{W}_{\mathrm{I}}\right) /$ duration period.

Where:

$$
\mathrm{Ln}=\text { Natural } \log \text { and } \mathrm{n} \text { is the duration period in days. }
$$

\section{Measurement of feed and nutrient utilization:}

1- Feed conversion ratio $(\mathrm{FCR})=$ dry matter intake $(\mathrm{g}) /$ total gain $(\mathrm{g})$.

2- Protein efficiency ratio $(\mathrm{PER})=$ total gain $(\mathrm{g}) /$ protein intake $(\mathrm{g})$.

3- Protein productive value $(\mathrm{PPV} \%)=\left(\mathrm{P}_{\mathrm{T}}-\mathrm{P}_{\mathrm{I}}\right) \times 100 /$ protein intake $(\mathrm{g})$.

Where:

$$
\mathrm{P}_{\mathrm{T}}=\text { Protein content in fish carcass at the end. }
$$

$\mathrm{P}_{\mathrm{I}}=$ Protein content at the start.

4- Energy utilization $(\mathrm{EU} \%)=\left(\mathrm{E}_{\mathrm{T}}-\mathrm{E}_{\mathrm{I}}\right) \times 100 /$ Energy intake $(\mathrm{kcal})$.

Where:

$$
\begin{aligned}
& \mathrm{E}_{\mathrm{T}}=\text { Energy in fish carcass }(\mathrm{kcal}) \text { at the end. } \\
& \mathrm{E}_{\mathrm{I}}=\text { Energy in fish carcass (kcal) at the start. }
\end{aligned}
$$

\section{Statistical analysis:}

Statistically analyzed data was done using one-way classification using the feature PROC UNIVARIATE of the software SAS (Statistical Analysis System, version 6.10).Duncan's multiple range test was used to compare differences between treatment means when significance $\mathrm{F}$ values were observed Duncan, (1955), at $\mathrm{P} \leq 0.05$ level. Data were submitted to analysis of variance (two-way ANOVA) to identify significant differences $(\mathrm{P}<0.05)$ between treatments.

\section{Results}

\section{1- Water quality:}

Water quality parameters recorded during the experimental period were within the following ranges:

1- Dissolved oxygen: it was varied from 6 to $7.5 \mathrm{mg} / \mathrm{l}$.

2- Water temperature: it was monitored at 27 to $30{ }^{\circ} \mathrm{C}$.

3- Hydrogen ion concentration $(\mathrm{pH})$ : it was fluctuated between 7.0 and 8.5.

4- Ammonia: it was varied from 0.01 to $0.08 \mathrm{mg} / \mathrm{l}$.

5 - Nitrate $\left(\mathrm{NO}_{3}\right)$ : it was fluctuated between 5 to $15 \mathrm{ppm}$.

6- Nitrite $\left(\mathrm{NO}_{2}\right)$ : it was varied from 0.01 to $0.09 \mathrm{ppm}$.

7- Salinity: it was varied from 2 to $4 \%$

\section{2- Chemical composition of the artificial diets:}

Proximate composition of the experimental diet is shown in Table (4). The basal experimental diet was formulated to contented $4 \leqslant .04 \%$ CP, $5 . \cdot 8 \%$ crude fat, $29.02 \%$ total carbohydrate, $415.90(\mathrm{kcal} / 100 \mathrm{~g})$ gross energy (GE) and $105.89(\mathrm{mg} \mathrm{CP} / \mathrm{Kcal} \mathrm{GE})$ protein energy ratio (P:E ratio) according to Teshima et al. (2006). 
Data showed that, the dry matter nearly similar in results; being $94.35,94.03$ and 95.25in the diet contained (AC), (AB), and (A) extracts respectively and 93.41 and 93.22 the diet contained (C) and (BC) extracts as feed additives respectively against control as (94.12). Shown in Table (4)

Another observation was detected in ether extract; the lowest value of ether extract was recorded in the diet contained $(\mathrm{ABC})$ and $(\mathrm{C}) 0.05 \%$ extracts as 0.12 and 0.16 respectively and reached it maximum values ( 0.95 and 0.94 respectively) in the diet (B) and (AC) $0.05 \%$ extracts as feed additives.

The minimum values of crude protein were recorded in the diet contained (C) and (ABC) $0.05 \%$ extracts as 44.12 and 44.21 respectively and reached it maximum values (44.86 and 44.78 respectively) in the diet (B) and (A) $0.05 \%$ extracts as feed additives.

The minimum values of nitrogen free extract were recorded in the diet contained (B) and (BC) $0.05 \%$ extracts as 27.29 and 27.85 respectively and reached it maximum values (30.79 and 29.19 respectively) in the $\operatorname{diet}(\mathrm{A})$ and (C) $0.05 \%$ extracts as feed additives.

The minimum values of gross energy $(\mathrm{kcal} / 100 \mathrm{~g})$ were recorded in the diet contained $(\mathrm{ABC})$ and $(\mathrm{C}) 0.05 \%$ extracts as 412.67 and 417.81 respectively and reached it maximum values (428.79 and 427.08 respectively) in the diet (A) and (AC) $0.05 \%$ extracts as feed additives.

The Effect of different plant extract treatments on the growth performance of the fresh water prawn, $M$. rosenbergii, post larva are shown in Table (5 and 6)

The final weight obtained by the prawn fed diets contained (B), (AB) and (A) extracts is significantly at $(\mathrm{P}<0.05)$ higher than the fish fed the same diets with other extracts as (ABC), (AC), $(\mathrm{C})$ and $(\mathrm{BC})$; being $8.13 \pm 0.24,7.55 \pm 0.21$ and $7.31 \pm 0.15$ respectively in the formers and $6.76 \pm 0.23,5.43 \pm 0.22,4.75 \pm 0.12$ and $4.23 \pm 0.07$ respectively in the latter's against control as $3.62 \pm 0.04$. In general, the maximum value $(8.13 \pm 0.24)$ was recorded in the prawn fed with diet contained extract $(B)$ and the minimum value $(4.23 \pm 0.07)$ occurred in the prawn fed with diet contained extract (BC).

Total weight gain $(\mathrm{g} / \mathrm{pl})$ is relatively similar to the final weight of the prawn fed with different plant extract treatments. The Total weight gain (g/PL) obtained by the prawn fed diets contained $(\mathrm{B}),(\mathrm{AB})$ and $(\mathrm{A})$ extracts is significantly at $(\mathrm{P}<0.05)$ higher than the $M$. rosenbergii (PL) fed with the same diets with other extracts as (ABC), (AC), (C) and (BC); being $8.04 \pm 0.24,7.46 \pm 0.22$ and $7.22 \pm 0.15$ respectively in the formers and $6.67 \pm 0.20$, $5.34 \pm 0.21,4.66 \pm 0.12$ and $4.14 \pm 0.08$ respectively in the latter's against control as $3.53 \pm$ 0.04 . In general, the maximum value $(8.04 \pm 0.24)$ was recorded in the prawn fed with diet contained extract $(B)$ and the minimum value $(4.14 \pm 0.08)$ occurred in the prawn fed with diet contained extract (BC).

The best average daily gain $(0.10 \pm 0.003 \mathrm{~g} / \mathrm{prawn} / \mathrm{day})$ was obtained by the $M$. rosenbergii (PL) fed on diet contained extract (B). However, no significant differences $(\mathrm{P}>0.05)$ were observed between diets containing $(\mathrm{C})$ and $(\mathrm{BC})$ extract.

The lower significant average daily gain was obtained by M. rosenbergii (PL) fed with control diet void of any additives and diet containing (BC) extract. 
Results of specific growth rate (\% day) showed that highly significantly difference at $(\mathrm{P}>0.05)$ between data. The specific growth rate (\% day) obtained by the $M$. rosenbergii (PL) fed diets contained $(\mathrm{B}),(\mathrm{AB})$ and $(\mathrm{A})$ extracts is significantly at $(\mathrm{P}<0.05)$ higher than the $M$. rosenbergii (PL) fed with the same diets with other extracts as (ABC), $(\mathrm{AC}),(\mathrm{C})$ and $(\mathrm{BC})$; being $5.35 \pm 0.02,5.23 \pm 0.03$ and $5.20 \pm 0.04$ respectively in the formers and $5.10 \pm 0.06$, $4.84 \pm 0.04,4.69 \pm 0.02$ and $4.55 \pm 0.05$ respectively in the latter's against control as $4.34 \pm$ 0.01 .

\section{3- Feed and nutrient utilization of $M$. rosenbergii (PL):}

The Effect of different plant extract treatments on the feed and nutrient utilization parameters of the fresh water prawn, M. rosenbergii, post larva are shown in Table (7 and 8)

The highest values of feed consumption were obtained by the $M$. rosenbergii (PL) fed with $0.05 \%$ of peanuts, Arachis Hypogaea (A), $0.05 \%$ of sesames, Sesamum Indicum (B) extract ; being $21.27 \pm 0.49$ and $21.05 \pm 0.14$ respectively. Feed intake in the $M$. rosenbergii (PL) fed with (AC) and (C) extract were nearly similar; being $17.98 \pm 0.55$ in the former and $17.04 \pm 0.06$ in the latter. It was followed by diet contained (BC) extract as $(16.13 \pm 0.15)$.

The highest protein intake was obtained by the diet with (B) and (A) extracts and the lowest in the diet of $(\mathrm{BC})$ extract; the proportions being $9.48 \pm 0.04$ and $9.38 \pm 0.18$ in the former and $7.22 \pm 0.08$ in the latter.

The highest feed conversion ratio was obtained by the diet with (BC) and (C) extracts and the lowest in the diet of (B) extract; the proportions being 3.90 \pm 0.10 and $3.66 \pm 0.08$ in the former and $2.62 \pm 0.06$ in the latter.

Results revealed that, both protein efficiency ratio and protein productive values were highly significant at $(\mathrm{P}<0.05)$ increases with the diet containing $(\mathrm{B}),(\mathrm{AB})$ and $(\mathrm{A})$ extracts. It was followed diet containing $(\mathrm{ABC})$ and $(\mathrm{AC})$ extracts. Data showed that, protein efficiency ratio $(0.85 \pm 0.02)$ was the best with $M$. rosenbergii $(\mathrm{PL})$ fed diet contained (B) extract and the lowest was $(0.57 \pm 0.02)$ with $M$. rosenbergii $(\mathrm{PL})$ fed diet contained (BC) extract.

The best protein productive value $(14.10 \pm 0.26)$ was observed with $M$. rosenbergii (PL) fed diet containing (B) extract and the lowest was $(8.76 \pm 0.45)$ with diet contained (BC) extract.

Results showed that, energy utilization were high significantly different at $(\mathrm{P}>0.05)$ when $M$. rosenbergii (PL) fed with diets containing $(\mathrm{B}),(\mathrm{C}),(\mathrm{BC})$ and $(\mathrm{AC})$ extracts. The highest energy utilization was obtained by the diet with the diets containing $(B),(A B C)$ and (A) extracts and the lowest in the diets containing (C) and (BC) extract; being 13.02 \pm 0.24 , $11.57 \pm 0.09$ and $11.17 \pm 0.10$ in the former and $8.63 \pm 0.19^{\mathrm{d}}$ and $8.37 \pm 0.33$ in the latter. On the other hand, no significantly different at $(\mathrm{P}>0.05)$ when $M$. rosenbergii $(\mathrm{PL})$ fed with diets containing $(\mathrm{ABC}),(\mathrm{AB})$, and $(\mathrm{A})$ extracts; being $11.57 \pm 0.09,11.46 \pm 0.44$ and $11.17 \pm 0.10$ respectively.

\section{4- Carcass composition of $M$. rosenbergii (PL):}

Data showed that, the dry matter nearly similar in results; being $25.78 \pm 0.24,25.45 \pm$ 0.29 and $25.25 \pm 0.23$ in the diet contained (B), (AC), and (A) extracts respectively and 24.95 $\pm 0.08,24.92 \pm 0.40$ and $24.86 \pm 0.43$ the diet contained $(\mathrm{AB}),(\mathrm{ABC})$, and $(\mathrm{C})$ extracts as feed additives respectively shown in table (9 and 10). 
Another observation was detected in crude protein; the lowest value of crude protein was recorded in the diet contained (C) and (BC) $0.05 \%$ extracts as $60.90 \pm 1.62$ and $60.97 \pm$ 1.93 respectively and reached it maximum values $(66.70 \pm 0.52$ and $65.62 \pm 0.01$ respectively) in the diet $(\mathrm{B})$ and $(\mathrm{AB}) 0.05 \%$ extracts as feed additives.

The minimum values of ether extract were recorded in the diet contained (B) and (AB) $0.05 \%$ extracts as $21.13 \pm 0.02$ and $21.26 \pm 0.02$ respectively and reached it maximum values $(21.80 \pm 0.05$ and $21.67 \pm 0.18$ respectively) in the diet $(\mathrm{BC})$ and $(\mathrm{C}) 0.05 \%$ extracts as feed additives.

The highest values of ash was recorded the diet contained (C) and (AC) $0.05 \%$ extracts; being $17.44 \pm 1.80$ and $17.33 \pm 1.78$ respectively and the lowest was $(12.17 \pm 0.50$ and $13.13 \pm 0.01$ ) with $M$. rosenbergii (PL) fed diet contained (B) and (AB) $0.05 \%$ extracts.

Results revealed significant differences in the energy content (kcal/100gm) among different plant extracts. The minimum values of energy content $(\mathrm{kcal} / 100 \mathrm{gm})$ were recorded in the diet contained (C) and (BC) $0.05 \%$ extracts as $542.92 \pm 8.95$ and $546.76 \pm 4.16$ respectively and reached it maximum values (582.02 \pm 1.74 and $579.10 \pm 6.21$ respectively) in the diet (AB) and (B) $0.05 \%$ extracts as feed additives.

Results revealed that, values of dry matter, crude protein, ether extract and energy content $(\mathrm{kcal} / 100 \mathrm{~g})$ were significantly different at $(\mathrm{P}<0.05)$ but there are no significant difference in ash content data among different plant extract treatments as feed additive.

The results obtained in Table (13 and 14) showed that petroleum ether extract of Sesamum indicum (B) had a very strong antimicrobial effect against Vibiro cholerae, Vibiro alginolyticus and Vibiro carchariae as $20.8 \pm 0.62,19.6 \pm 0.62$ and $18.6 \pm 0.34$ respectively against control gentamycine as $(23.8 \pm 0.2,20.3 \pm 0.3$ and $23.8 \pm 0.2$ respectively). Followed with extract of peanuts, Arachis Hypogaea (A) had a very strong antimicrobial effect against Vibiro cholerae, Vibiro alginolyticus and Vibiro carchariae as $15.2 \pm 0.58,12.9 \pm$ 0.19 and $13.5 \pm 0.34$ respectively against control gentamycine as $(23.8 \pm 0.2,20.3 \pm 0.3$ and $23.8 \pm 0.2$ respectively), but the ether extract of sun flower seeds, Helianthus Annuus (C) had a mild antimicrobial effect against Vibiro cholerae, Vibiro alginolyticus and Vibiro carchariae as (13.1 $\pm 0.62,12.3 \pm 0.22$ and $10.2 \pm 0.39)$ respectively against control (Gentamycine) as (23.8 $\pm 0.2,20.3 \pm 0.3$ and $23.8 \pm 0.2$ respectively).

The best petroleum ether extracts have very strong antimicrobial effect against Aeromonas caviea were Sesamum indicum (B) and Helianthus Annuus (C) as (17.4 \pm 0.38 and $13.9 \pm 0.45)$ respectively and the lowest was Arachis Hypogaea (A) as (13.2 \pm 0.67$)$ against control (Gentamycine) as $(28.3 \pm 0.1)$.We can noted that nearly similar in results between extracts (C) and (A) against Aeromonas caviea.

Another observation revealed the best antifungal effect against Aspergillus parasiticus with Sesamum indicum (B) extract as $(17.8 \pm 0.46)$ compared with control (Amphotericin B) as $(21.9 \pm 0.12)$ but mild effect against Aspergillus parasiticus were noted with Helianthus Annuus (C) and Arachis Hypogaea (A) extracts being; $13.4 \pm 0.63$ in the former and $12.7 \pm$ 0.55 in the latter compared with control (Amphotericin B) as $(21.9 \pm 0.12)$

There are no antifungal activities of all extracts (A), (B) and (C) against Fusarium graminearum, Penicillium verrucosum and Candida albicans fungi compared with control (Amphotericin B) as (25.4 $\pm 0.1,26.3 \pm 0.37$ and $20.9 \pm 0.3)$ respectively. 
Another observation was detected in fatty acid content of Sesamum indicum (B) extract was as $13.51 \%$ Palmitoleic (C16:1), 4.47\% Heptadecanoic(C17), $47.14 \%$ Oleic(C18:1), 9.35\% Stearic(C18), 3.35\% Linoleic (C18:2) and 22.19\% Linolenic(C18:3). The best fatty acid percentages with Oleic $(\mathrm{C} 18: 1)$ as $(47.14 \%)$ and lowest with Linoleic $(\mathrm{C} 18: 2)$ as $(3.35 \%)$.shown in table (11 and 12$)$ graphically represented with figure $(1,2$ and $3)$.

On other hand, fatty acid content of Helianthus Annuus (C) extract was as $37.23 \%$ Oleic(C18:1), $33.07 \%$ Stearic(C18) and $29.70 \%$ Palmitic(C16). The best fatty acid percentages with Oleic (C18:1) as (37.23\%) and lowest with Palmitic(C16) as (29.70\%).

The best percentages of Oleic acid (18:1 ڤं-9) occurred within Sesamum indicum (B) and Helianthus Annuus (C) were (47.14\% and 37.23\%) respectively with retention time being; 19.39 in the former and 19.29 in the latter but the lowest occurred within Arachis Hypogaea (A) extract was (4.86\%) with retention time as (19.97).

The best percentages of Palmitoleic acid (16:1 $\dot{\omega}-7)$ occurred within Helianthus Annuus (C) was (29.70\%) with retention time as (16.22) but the lowest occurred within Arachis Hypogaea (A) was (21.20\%) with retention time as (16.74).

Table (1): Percentage composition of the artificial diet consumed by the prawn and fish cultivated in lab experiments.

\begin{tabular}{||c|c||c|}
\hline \multicolumn{2}{|c||}{$45 \%$ crude protein } & \multirow{2}{*}{ Ingredient } \\
\hline Percentages $/ \mathrm{kg}$ & $\mathrm{gm} / \mathrm{kg}$ & \\
\hline 35 & 350 & Fish meal \\
\hline 35 & 350 & Soybean meal \\
\hline 14 & 140 & Rice bran \\
\hline 11 & 110 & Yellow corn meal \\
\hline 3 & 30 & Yellow corn oil \\
\hline 1 & 10 & Vit. Mixture \\
\hline 1 & 10 & Min. mixture \\
\hline
\end{tabular}

Table (2): Dietary levels of minerals per $\mathrm{mg} / \mathrm{kg}$ in lab experiment.

\begin{tabular}{|c|c|}
\hline Concentration & Element \\
\hline $325 \mathrm{mg} / \mathrm{kg}$ & Manganese \\
\hline $200 \mathrm{mg} / \mathrm{kg}$ & Iron \\
\hline $25 \mathrm{mg} / \mathrm{kg}$ & Copper \\
\hline $5 \mathrm{mg} / \mathrm{kg}$ & lodine \\
\hline $5 \mathrm{mg} / \mathrm{kg}$ & Cobalt \\
\hline
\end{tabular}


Table (3): Dietary levels of vitamins per Kg in lab experiment.

\begin{tabular}{|c|c|}
\hline Concentration & Vitamin \\
\hline $3300 \mathrm{IU}$ & vitamin A \\
\hline $410 \mathrm{IU}$ & vitamin D \\
\hline $2660 \mathrm{mg}$ & vitamin E2 \\
\hline $133 \mathrm{mg}$ & vitamin B \\
\hline $580 \mathrm{mg}$ & vitamin B6 \\
\hline $410 \mathrm{mg}$ & vitamin B12 \\
\hline $4000 \mathrm{mg}$ & vitamin C \\
\hline $50 \mathrm{mg}$ & Biotin \\
\hline $9330 \mathrm{mg}$ & Colin chloride \\
\hline $2660 \mathrm{mg}$ & Inositol \\
\hline $330 \mathrm{mg}$ & Para- amino benzoic acid \\
\hline $9330 \mathrm{mg}$ & Niacin \\
\hline $2660 \mathrm{mg}$ & Pantothenic acid \\
\hline
\end{tabular}

Table (4): Percentage composition of the artificial (tested) diets utilized in the laboratory experiment.

\begin{tabular}{|c|c|c|c|c|c|c|c|c|}
\hline \multirow[b]{2}{*}{ Diets } & \multicolumn{5}{|c|}{ \% On dry matter basis } & \multirow{2}{*}{$\begin{array}{l}\text { Nitrogen } \\
\text { free } \\
\text { extract }\end{array}$} & \multirow{2}{*}{$\begin{array}{c}\text { Gross } \\
\text { energy } \\
\text { (kcal/100g) }\end{array}$} & \multirow{2}{*}{$\begin{array}{c}\mathrm{P} / \mathrm{E} \\
\text { ratio } \\
(\mathrm{mg} \\
\mathrm{CP} \\
/ \text { Kcal } \\
\text { GE) }\end{array}$} \\
\hline & $\begin{array}{c}\text { Dry } \\
\text { matter }\end{array}$ & $\begin{array}{c}\text { Ether } \\
\text { extract }\end{array}$ & $\begin{array}{l}\text { Crude } \\
\text { protein }\end{array}$ & Ash & $\begin{array}{l}\text { Crude } \\
\text { fibers }\end{array}$ & & & \\
\hline Control & 94.12 & $5 . \cdot 8$ & $4 \leqslant .04$ & 13.37 & 2.59 & 29.02 & 415.90 & 105.89 \\
\hline $\mathbf{A}$ & 95.25 & $0 . r 3$ & 44.78 & 12.31 & 2.14 & 30.79 & 428.79 & 104.43 \\
\hline $\mathbf{B}$ & 92.35 & 0.95 & $4 \leqslant . \wedge 6$ & 12.11 & 2.14 & 27.29 & 421.61 & 106.40 \\
\hline $\mathbf{C}$ & 93.41 & 0.16 & 44.12 & 12.68 & 2.25 & 29.19 & 417.81 & 105.60 \\
\hline AB & 94.03 & 0.76 & $4 \leqslant .74$ & 12.56 & 2.16 & 28.78 & 425.28 & 105.20 \\
\hline $\mathbf{A C}$ & 94.35 & 0.94 & $4 £ .56$ & 12.61 & 2.19 & 29.05 & 427.08 & 104.34 \\
\hline$\overline{\mathrm{BC}}$ & 93.22 & 0.84 & $4 \leqslant .74$ & 12.61 & 2.16 & 27.85 & 422.21 & 105.97 \\
\hline$\overline{\mathrm{ABC}}$ & 92.43 & 0.12 & 44.21 & 12.81 & 2.35 & 27.91 & 412.67 & 107.13 \\
\hline
\end{tabular}


Table (5): Effect of different plant extracts on the growth performance of the fresh water prawn, $M$. rosenbergii, post larva.

\begin{tabular}{|c|c|c|c|c|c|c|}
\hline \multirow[b]{2}{*}{ Treatment } & \multicolumn{2}{|c|}{ Body weight } & \multirow[b]{2}{*}{$\begin{array}{l}\text { Total weight } \\
\text { gain }(\mathrm{g} / \text { prawn })\end{array}$} & \multirow{2}{*}{$\begin{array}{c}\text { Average daily gain } \\
\text { (ADG) } \\
\text { (g/prawn/day) }\end{array}$} & \multirow[b]{2}{*}{$\begin{array}{l}\text { Survival } \\
\text { Rate }(\%)\end{array}$} & \multirow{2}{*}{$\begin{array}{c}\text { Specific } \\
\text { growth rate } \\
\text { (SGR) } \\
\text { (\%/day) }\end{array}$} \\
\hline & $\begin{array}{c}\text { Initial } \\
\text { (g/prawn) }\end{array}$ & $\begin{array}{c}\text { Final } \\
\text { (g/prawn) }\end{array}$ & & & & \\
\hline Control & $0.01 \pm 0.02^{\mathrm{a}}$ & $3.62 \pm 0.04^{\mathrm{f}}$ & $3.53 \pm 0.04^{\mathrm{f}}$ & $0.05 \pm 0.0005^{\mathrm{f}}$ & $\begin{array}{c}66.25 \pm \\
0.05^{\mathrm{g}} \\
\end{array}$ & $4.34 \pm 0.01^{\mathrm{g}}$ \\
\hline A & $0.09 \pm 0.01^{\mathrm{a}}$ & $7.31 \pm 0.15^{\mathrm{bc}}$ & $7.22 \pm 0.15^{\mathrm{bc}}$ & $0.09 \pm 0.002^{\mathrm{bc}}$ & $\begin{array}{c}78.75 \pm \\
0.01^{\mathrm{c}} \\
\end{array}$ & $5.20 \pm 0.04^{b c}$ \\
\hline B & $0.09 \pm 0.01^{\mathrm{a}}$ & $8.13 \pm 0.24^{\mathrm{a}}$ & $8.04 \pm 0.24^{\mathrm{a}}$ & $0.10 \pm 0.003^{\mathrm{a}}$ & $\begin{array}{c}87.50 \pm \\
0.03^{\mathrm{a}}\end{array}$ & $5.35 \pm 0.02^{\mathrm{a}}$ \\
\hline $\mathrm{C}$ & $0.01 \pm 0.01^{\mathrm{a}}$ & $4.75 \pm 0.12^{\mathrm{e}}$ & $4.66 \pm 0.12^{\mathrm{e}}$ & $0.06 \pm 0.001^{\mathrm{e}}$ & $\begin{array}{l}72.50 \pm \\
0.02^{\mathrm{e}}\end{array}$ & $4.69 \pm 0.02^{\mathrm{e}}$ \\
\hline $\mathrm{AB}$ & $0.09 \pm 0.01^{\mathrm{a}}$ & $7.55 \pm 0.21^{\mathrm{b}}$ & $7.46 \pm 0.22^{\mathrm{b}}$ & $0.09 \pm 0.002^{b}$ & $\begin{array}{c}82.50 \pm \\
0.01^{\mathrm{b}}\end{array}$ & $5.23 \pm 0.03^{b}$ \\
\hline $\mathrm{AC}$ & $0.09 \pm 0.01^{\mathrm{a}}$ & $5.43 \pm 0.22^{\mathrm{d}}$ & $5.34 \pm 0.21^{\mathrm{d}}$ & $0.06 \pm 0.003^{\mathrm{d}}$ & $\begin{array}{r}75.00 \pm \\
0.04^{\mathrm{d}}\end{array}$ & $4.84 \pm 0.04^{\mathrm{d}}$ \\
\hline $\mathrm{BC}$ & $0.09 \pm 0.02^{\mathrm{a}}$ & $4.23 \pm 0.07^{\mathrm{e}}$ & $4.14 \pm 0.08^{\mathrm{e}}$ & $0.05 \pm 0.001^{\mathrm{e}}$ & $\begin{array}{c}68.75 \pm \\
0.11^{\mathrm{f}}\end{array}$ & $4.55 \pm 0.05^{\mathrm{f}}$ \\
\hline $\mathrm{ABC}$ & $0.09 \pm 0.02^{\mathrm{a}}$ & $6.76 \pm 0.23^{\mathrm{c}}$ & $6.67 \pm 0.20^{\mathrm{c}}$ & $0.08 \pm 0.003^{\mathrm{c}}$ & $\begin{array}{c}77.50 \pm \\
0.21^{\mathrm{c}}\end{array}$ & $5.10 \pm 0.06^{\mathrm{c}}$ \\
\hline Overall mean & 0.09 & 5.97 & 5.88 & 0.07 & 76.09 & 4.91 \\
\hline L.S.D $(\mathrm{P}<0.05)$ & 0.004 & 0.56 & 0.56 & 0.007 & 6.11 & 0.11 \\
\hline (C.V\%) & 1.70 & 4.04 & 4.10 & 4.15 & 5.45 & 0.93 \\
\hline
\end{tabular}

The mean in the same column bearing different superscript are significantly different at $(\mathrm{P}<.05)$. Means followed by the same letter are not significant, but different letter's are significant. L.S.D: Least Significant Difference.

(C.V\%): Coefficient of Variation.

Table (6): Analysis of variance (mean square) of growth performance of the fresh water prawn, $M$. rosenbergii, post larva fed on diets containing different treatment of plant extracts.

\begin{tabular}{|c|c|c|c|c|c|c|}
\hline \multirow[b]{2}{*}{$\begin{array}{c}\text { Analysis of } \\
\text { variance } \\
\text { (A.O.V) }\end{array}$} & \multirow[b]{2}{*}{$\begin{array}{l}\text { Degrees } \\
\text { of } \\
\text { freedom }\end{array}$} & \multicolumn{2}{|c|}{ Body weight } & \multirow{2}{*}{$\begin{array}{c}\text { Total } \\
\text { weight } \\
\text { gain } \\
\text { (g/prawn) }\end{array}$} & \multirow[b]{2}{*}{$\begin{array}{l}\text { Average daily } \\
\text { gain (ADG) } \\
\text { (g/prawn/day) }\end{array}$} & \multirow{2}{*}{$\begin{array}{c}\text { Specific } \\
\text { growth } \\
\text { rate } \\
\text { (SGR) } \\
\text { (\%/day) }\end{array}$} \\
\hline & & $\begin{array}{c}\text { Initial } \\
\text { (g/prawn) }\end{array}$ & $\begin{array}{c}\text { Final } \\
\text { (g/prawn) }\end{array}$ & & & \\
\hline Treatment & V & $0.0002^{\text {n.s }}$ & $5.69 * * *$ & $5.69 * * *$ & $0.0008 * * *$ & $0.26 * * *$ \\
\hline Error & $\Lambda$ & 0.0003 & 0.06 & 0.07 & 0.0001 & 0.002 \\
\hline Total & 10 & 0.0005 & 0.10 & $0 . \wedge r$ & $\because \cdots \wedge$ &.$r v$ \\
\hline
\end{tabular}

$* * *$ Denotes significant differences in data at $(\mathrm{P}<0.001)$ level of probability respectively.

n.s Denotes no significant differences in data. 
Table (7): Effect of different plant extract treatments on feed and nutrient utilization parameters of the fresh water prawn, $M$. rosenbergii, post larva.

\begin{tabular}{|c|c|c|c|c|c|c|}
\hline \multirow[b]{2}{*}{ Treatment } & \multirow[b]{2}{*}{$\begin{array}{l}\text { Feed intake } \\
\text { (gm/prawn) }\end{array}$} & \multirow[b]{2}{*}{$\begin{array}{c}\text { protein intake } \\
\text { (gm/prawn) }\end{array}$} & \multirow[b]{2}{*}{$\begin{array}{c}\text { Food } \\
\text { conversion } \\
\text { ratio }(\text { FCR })\end{array}$} & \multicolumn{2}{|c|}{ Protein utilization } & \multirow[b]{2}{*}{$\begin{array}{c}\text { Energy } \\
\text { utilization } \\
\text { (EU\%) }\end{array}$} \\
\hline & & & & $\begin{array}{c}\text { Protein } \\
\text { efficiency } \\
\text { ratio (PER) }\end{array}$ & $\begin{array}{c}\text { Protein } \\
\text { productive } \\
\text { value } \\
(\text { PPV\%) } \\
\end{array}$ & \\
\hline Control & $14.49 \pm 0.30^{\mathrm{d}}$ & $6.48 \pm 0.12^{\mathrm{c}}$ & $4.11 \pm 0.04^{\mathrm{a}}$ & $0.54 \pm 0.04^{\mathrm{f}}$ & $8.98 \pm 0.12^{\mathrm{d}}$ & $8.61 \pm 0.08^{d}$ \\
\hline $\mathbf{A}$ & $21.27 \pm 0.49^{\mathrm{a}}$ & $9.38 \pm 0.18^{\mathrm{a}}$ & $2.95 \pm 0.13^{\text {ed }}$ & $0.77 \pm 0.03^{\mathrm{bc}}$ & $12.09 \pm 0.20^{b c}$ & $11.17 \pm 0.10^{b}$ \\
\hline B & $21.05 \pm 0.14^{\mathrm{a}}$ & $9.48 \pm 0.04^{a}$ & $2.62 \pm 0.06^{\mathrm{f}}$ & $0.85 \pm 0.02^{\mathrm{a}}$ & $14.10 \pm 0.26^{\mathrm{a}}$ & $13.02 \pm 0.24^{\mathrm{a}}$ \\
\hline C & $17.04 \pm 0.06^{\mathrm{bc}}$ & $7.33 \pm 0.07^{b}$ & $3.66 \pm 0.08^{b}$ & $0.64 \pm 0.01^{\mathrm{e}}$ & $9.16 \pm 0.08^{d}$ & $8.63 \pm 0.19^{d}$ \\
\hline $\mathbf{A B}$ & $21.11 \pm 0.97^{\mathrm{a}}$ & $9.24 \pm 0.43^{\mathrm{a}}$ & $2.83 \pm 0.05^{\mathrm{ef}}$ & $0.81 \pm 0.02^{\mathrm{ab}}$ & $12.48 \pm 0.63^{b}$ & $11.46 \pm 0.44^{b}$ \\
\hline $\mathbf{A C}$ & $17.98 \pm 0.55^{b}$ & $7.83 \pm 0.25^{b}$ & $3.37 \pm \mathbf{0 . 0 3}^{\mathrm{c}}$ & $0.68 \pm 0.01^{\mathrm{de}}$ & $11.42 \pm 0.16^{c}$ & $10.23 \pm 0.11^{\mathrm{c}}$ \\
\hline BC & $16.13 \pm 0.15^{c}$ & $7.22 \pm 0.08^{b}$ & $3.90 \pm 0.10^{a b}$ & $0.57 \pm 0.02^{\mathrm{f}}$ & $8.76 \pm 0.45^{d}$ & $8.37 \pm 0.33^{\mathrm{d}}$ \\
\hline $\mathbf{A B C}$ & $20.72 \pm 0.39^{\mathrm{a}}$ & $9.16 \pm 0.13^{\mathrm{a}}$ & $3.11 \pm 0.04^{\mathrm{d}}$ & $0.73 \pm 0.01^{\text {cd }}$ & $12.36 \pm 0.21^{\mathrm{bc}}$ & $11.57 \pm 0.09^{b}$ \\
\hline Overall mean & 18.72 & 8.27 & 3.32 & 0.70 & 11.17 & 10.53 \\
\hline L.S.D $(\mathbf{P}<0.05)$ & 1.53 & 0.66 & 0.24 & 0.05 & 1.03 & 0.76 \\
\hline (C.V\%) & 3.54 & 3.44 & 3.14 & $\mathbf{3 . 3 6}$ & 3.98 & 3.11 \\
\hline
\end{tabular}

The mean in the same column bearing different superscript are significantly different at $(\mathrm{P}<$ $0.05)$.

Means followed by the same letter are not significant, but different letter's are significant.

L.S.D: Least Significant Difference.

(C.V\%): Coefficient of Variation.

Table (8): Analysis of variance (mean square) of feed and nutrient utilization of the fresh water prawn, $M$. rosenbergii, post larva fed on diets containing different treatment of plant extracts.

\begin{tabular}{|c|c|c|c|c|c|c|c|}
\hline \multirow[b]{2}{*}{$\begin{array}{c}\text { Analysis of } \\
\text { variance } \\
\text { (A.O.V) }\end{array}$} & \multirow[b]{2}{*}{$\begin{array}{l}\text { Degrees of } \\
\text { freedom }\end{array}$} & \multirow[b]{2}{*}{$\begin{array}{l}\text { Feed intake } \\
\text { (gm/prawn) }\end{array}$} & \multirow[b]{2}{*}{$\begin{array}{c}\text { protein } \\
\text { intake } \\
\text { (gm/prawn) }\end{array}$} & \multirow[b]{2}{*}{$\begin{array}{c}\text { Food } \\
\text { conversion } \\
\text { ratio }(\mathrm{FCR})\end{array}$} & \multicolumn{2}{|c|}{ Protein utilization } & \multirow[b]{2}{*}{$\begin{array}{c}\text { Energy } \\
\text { utilization } \\
(\text { EU\%) }\end{array}$} \\
\hline & & & & & $\begin{array}{c}\text { Protein } \\
\text { efficiency } \\
\text { ratio (PER) }\end{array}$ & $\begin{array}{c}\text { Protein } \\
\text { productive } \\
\text { value } \\
(\text { PPV \%) }\end{array}$ & \\
\hline Treatment & 7 & $14.18 * * *$ & $2.81 * * *$ & $0.57 * * *$ & $0.02 * * *$ & $7.79 * * *$ & $6.53 * * *$ \\
\hline Error & $\Lambda$ & 0.44 & 0.08 & 0.02 & 0.001 & 0.20 & 0.11 \\
\hline Total & 15 & $1 \varepsilon .74$ & Y.^q & .01 & $\because \cdot r$ & 8.99 & 6.64 \\
\hline
\end{tabular}

*** Denotes significant differences in data at $(\mathrm{P}<0.001)$ level of probability respectively. 
Table (9): Effect of different plant extract treatments on chemical composition of whole body parameter of the fresh water prawn, $M$. rosenbergii, post larva.

\begin{tabular}{|c|c|c|c|c|c|}
\hline \multirow{2}{*}{ Treatment } & \multirow{2}{*}{ Dry Matter\% } & \multicolumn{3}{|c|}{$\%$ On dry matter basis } & \multirow{2}{*}{$\begin{array}{c}\text { Energy Content } \\
\text { (Kcal/100g) }\end{array}$} \\
\hline & & Crude Protein & Ether Extract & Ash & \\
\hline Control & $24.50 \pm 0.07^{\mathrm{c}}$ & $58.67 \pm 0.39^{c}$ & $22.45 \pm 0.19^{\mathrm{a}}$ & $18.88 \pm 0.20^{a}$ & $532.91 \pm 2.68^{\mathrm{c}}$ \\
\hline $\mathbf{A}$ & $25.25 \pm 0.23^{b}$ & $64.85 \pm 0.38^{\mathrm{ab}}$ & $21.40 \pm 0.05^{\mathrm{bc}}$ & $13.76 \pm 0.43^{\text {abc }}$ & $570.29 \pm 0.42^{a b}$ \\
\hline B & $25.78 \pm 0.24^{\mathrm{a}}$ & $66.70 \pm 0.52^{\mathrm{a}}$ & $21.13 \pm 0.02^{c}$ & $12.17 \pm 0.50^{c}$ & $579.10 \pm 6.21^{\mathrm{a}}$ \\
\hline C & $24.86 \pm 0.43^{b c}$ & $60.90 \pm 1.62^{b c}$ & $21.67 \pm 0.18^{b c}$ & $17.44 \pm 1.80^{\mathrm{ab}}$ & $542.92 \pm 8.95^{\mathrm{bc}}$ \\
\hline $\mathbf{A B}$ & $24.95 \pm 0.08^{d}$ & $65.62 \pm 0.01^{a b}$ & $21.26 \pm 0.02^{b c}$ & $13.13 \pm 0.01^{b c}$ & $582.02 \pm 1.74^{\mathrm{a}}$ \\
\hline $\mathbf{A C}$ & $25.45 \pm 0.29^{b}$ & $61.18 \pm 1.43^{b c}$ & $21.50 \pm 0.35^{b c}$ & $17.33 \pm 1.78^{a b c}$ & $550.82 \pm 8.53^{\mathrm{abc}}$ \\
\hline BC & $23.71 \pm 0.24^{\mathrm{a}}$ & $60.97 \pm 1.93^{\mathrm{bc}}$ & $21.80 \pm 0.05^{b}$ & $17.24 \pm 1.98^{\text {abc }}$ & $546.76 \pm 4.16^{\mathrm{bc}}$ \\
\hline $\mathrm{ABC}$ & $24.92 \pm 0.40^{\mathrm{cd}}$ & $64.72 \pm 1.35^{\mathrm{ab}}$ & $20.50 \pm 0.35^{\mathrm{a}}$ & $13.79 \pm 1.70^{\mathrm{abc}}$ & $565.67 \pm 7.78^{\mathrm{ab}}$ \\
\hline Overall mean & 24.93 & 62.95 & 21.59 & 15.46 & 558.81 \\
\hline L.S.D $(\mathbf{P}<0.05)$ & 0.44 & 5.10 & 0.64 & 5.24 & 31.62 \\
\hline (C.V\%) & 1.04 & 3.52 & 1.29 & 14.69 & 2.45 \\
\hline
\end{tabular}

The mean in the same column bearing different superscript are significantly different at $(\mathrm{P}<.05)$. Means followed by the same letter are not significant, but different letter's are significant.

L.S.D: Least Significant Difference.

(C.V\%): Coefficient of Variation.

Table (10): Analysis of variance (mean square) of body composition and energy content of the whole body of the fresh water prawn, M. rosenbergii, post larva fed on diets containing different treatment of plant extracts.

\begin{tabular}{|c|c|c|c|c|c|c|}
\hline \multirow{2}{*}{ 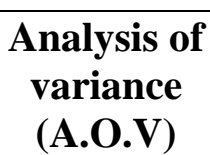 } & \multirow{2}{*}{$\begin{array}{l}\text { Degrees } \\
\text { of } \\
\text { freedom }\end{array}$} & \multirow[b]{2}{*}{$\begin{array}{c}\text { Dry } \\
\text { Matter\% }\end{array}$} & \multicolumn{3}{|c|}{$\%$ On dry matter basis } & \multirow{2}{*}{$\begin{array}{c}\text { Energy } \\
\text { Content } \\
(\text { Kcal/100g) }\end{array}$} \\
\hline & & & $\begin{array}{c}\text { Crude } \\
\text { Protein }\end{array}$ & $\begin{array}{c}\text { Ether } \\
\text { Extract }\end{array}$ & Ash & \\
\hline Treatment & $V$ & 0.902* & $16.44 *$ & $0.33 *$ & $12.64^{\mathrm{n} . \mathrm{s}}$ & 646.25* \\
\hline Error & $\Lambda$ & 0.221 & 4.90 & 0.08 & 5.16 & 188.03 \\
\hline Total & 10 & 1.123 & 21.34 & 0.41 & $\mathbf{1 7 . 8 0}$ & AT\&.YA \\
\hline
\end{tabular}

* Denotes significant differences in data at $(\mathrm{P}<0.05)$ level of probability respectively.

n.s Denotes no significant differences in data. 
Table (11): Result of qualitative estimation of lipoidal content of plant extracts.

\begin{tabular}{|c|c|c|l|}
\hline $\begin{array}{c}\text { Helianthus annuus } \\
(\mathrm{C})\end{array}$ & $\begin{array}{c}\text { Sesamum indicum } \\
(\mathrm{B})\end{array}$ & $\begin{array}{c}\text { Arachis hypogaea } \\
(\mathrm{A})\end{array}$ & \multirow{2}{*}{ Active Ingredient } \\
\hline \multicolumn{3}{|c|}{ Retention time } \\
\cline { 1 - 3 } 0.00 & 16.20 & 0.00 & \multirow{2}{*}{ Palmitoleic(C16:1) } \\
\hline 0.00 & 17.71 & 18.10 & \multirow{2}{*}{ Heptadecanoic(C17) } \\
\hline 19.29 & 19.39 & 19.97 & \multirow{2}{*}{ Oleic(C18:1) } \\
\hline 19.80 & 19.86 & 20.36 & Stearic(C18) \\
\hline 0.00 & 20.46 & 21.51 & Linoleic(C18:2) \\
\hline 0.00 & 20.95 & 0.00 & Linolenic(C18:3) \\
\hline 0.00 & 0.00 & 13.12 & Myristic(C14) \\
\hline 16.22 & 0.00 & 16.74 & Palmitic(C16) \\
\hline 0.00 & 0.00 & 28.13 & Behenic(C22) \\
\hline
\end{tabular}

Table (12): Result of quantitative estimation of lipoidal content of plant extracts.

\begin{tabular}{|c|c|c|l|}
\hline \multirow{3}{*}{ Helianthus annuus (C) } & Sesamum indicum (B) & Arachis hypogaea (A) & \multirow{2}{*}{ Active Ingredient } \\
\cline { 1 - 3 } & \multicolumn{3}{|c|}{ Percentages (\%) } \\
\hline 0.00 & 13.51 & 0.00 & \multirow{2}{*}{ Palmitoleic(C16:1) } \\
\hline 0.00 & 4.47 & 44.40 & Heptadecanoic(C17) \\
\hline 37.23 & 47.14 & 4.86 & Oleic(C18:1) \\
\hline 33.07 & 9.35 & 9.86 & Stearic(C18) \\
\hline 0.00 & 3.35 & 17.15 & Linoleic(C18:2) \\
\hline 0.00 & 22.19 & 0.00 & Linolenic(C18:3) \\
\hline 0.00 & 0.00 & 0.91 & Myristic(C14) \\
\hline 29.70 & 0.00 & 21.20 & Palmitic(C16) \\
\hline 0.00 & 0.00 & 1.62 & Behenic(C22) \\
\hline $100 \%$ & $100 \%$ & $100 \%$ & Total \\
\hline
\end{tabular}


Table (13): Result of anti fungal test on (A), (B) and (C) of plant extracts.

\begin{tabular}{|c|c|c|c|c|}
\hline $\begin{array}{c}\text { Tested } \\
\text { microorganisms }\end{array}$ & $\begin{array}{c}\text { Arachis } \\
\text { hypogaea }(\mathrm{A})\end{array}$ & $\begin{array}{c}\text { Sesamum } \\
\text { indicum } \text { (B) }\end{array}$ & $\begin{array}{c}\text { Helianthus } \\
\text { annuus }(\mathrm{C})\end{array}$ & $\begin{array}{c}\text { Stander } \\
\text { antifungal }\end{array}$ \\
\hline FUNGI & \multicolumn{2}{|l|}{ Amphotericin B } \\
\hline $\begin{array}{c}\text { Aspergillus flavus } \\
\text { (RCMB 02637) }\end{array}$ & $11.6 \pm 0.23$ & $16.3 \pm 0.35$ & $15.1 \pm 0.51$ & $23.7 \pm 0.1$ \\
\hline $\begin{array}{c}\text { Aspergillus parasiticus } \\
\text { ( RCMB 02348) }\end{array}$ & $12.7 \pm 0.55$ & $17.8 \pm 0.46$ & $13.4 \pm 0.63$ & $21.9 \pm 0.12$ \\
\hline $\begin{array}{c}\text { Fusarium } \\
\text { graminearum } \text { (RCMB } \\
\text { 08325) }\end{array}$ & NA & NA & NA & $25.4 \pm 0.1$ \\
\hline $\begin{array}{c}\text { Penicillium verrucosum } \\
\text { ( RCMB 04231) }\end{array}$ & NA & NA & NA & $26.3 \pm 0.37$ \\
\hline $\begin{array}{c}\text { Fusarium moniliforme } \\
\text { ( RCMB 08362) }\end{array}$ & $14.6 \pm 0.25$ & $20.3 \pm 0.25$ & $13.1 \pm 0.63$ & $21.0 \pm 0.58$ \\
\hline $\begin{array}{c}\text { Candida albicans } \\
\text { (RCMB 09124) }\end{array}$ & NA & NA & NA & $20.9 \pm 0.3$ \\
\hline
\end{tabular}

RCMB: Regional Center for Mycology and Biotechnology antimicrobial unit test organisms.

NA: No activity

Table (14): Result of anti bacterial test on (A), (B) and (C) of plant extracts.

\begin{tabular}{|c|c|c|c|c|}
\hline $\begin{array}{c}\text { Tested } \\
\text { microorganisms }\end{array}$ & $\begin{array}{c}\text { Arachis } \\
\text { hypogaea (A) }\end{array}$ & $\begin{array}{c}\text { Sesamum } \\
\text { indicum (B) }\end{array}$ & $\begin{array}{l}\text { Helianthus } \\
\text { annuus (C) }\end{array}$ & $\begin{array}{l}\text { Stander } \\
\text { antibiotic }\end{array}$ \\
\hline BACTERIA & & & & Gentamycine \\
\hline $\begin{array}{r}\text { Vibiro carchariae } \\
\text { ( RCMB 00125) }\end{array}$ & $13.5 \pm 0.34$ & $18.6 \pm 0.34$ & $10.2 \pm 0.39$ & $23.8 \pm 0.2$ \\
\hline $\begin{array}{l}\text { Vibiro alginolyticus } \\
\text { ( RCMB 001326) }\end{array}$ & $12.9 \pm 0.19$ & $19.6 \pm 0.62$ & $12.3 \pm 0.22$ & $20.3 \pm 0.3$ \\
\hline $\begin{array}{l}\text { Vibiro cholerae } \\
\text { ( RCMB 001421) }\end{array}$ & $15.2 \pm 0.58$ & $20.8 \pm 0.62$ & $13.1 \pm 0.62$ & $23.8 \pm 0.3$ \\
\hline $\begin{array}{r}\text { Aeromonas caviea } \\
\text { ( RCMB 003210) }\end{array}$ & $13.2 \pm 0.67$ & $17.4 \pm 0.38$ & $13.9 \pm 0.45$ & $28.3 \pm 0.1$ \\
\hline $\begin{array}{l}\text { Aeromonas hydrophila } \\
\text { ( RCMB 003224) }\end{array}$ & NA & NA & NA & $18.2 \pm 0.1$ \\
\hline $\begin{array}{l}\text { Pseudomonas fluorescens } \\
\text { ( RCMB 0003234) }\end{array}$ & NA & NA & NA & $20.4 \pm 0.6$ \\
\hline
\end{tabular}

RCMB: Regional Center for Mycology and Biotechnology antimicrobial unit test organisms.

NA: No activity. 


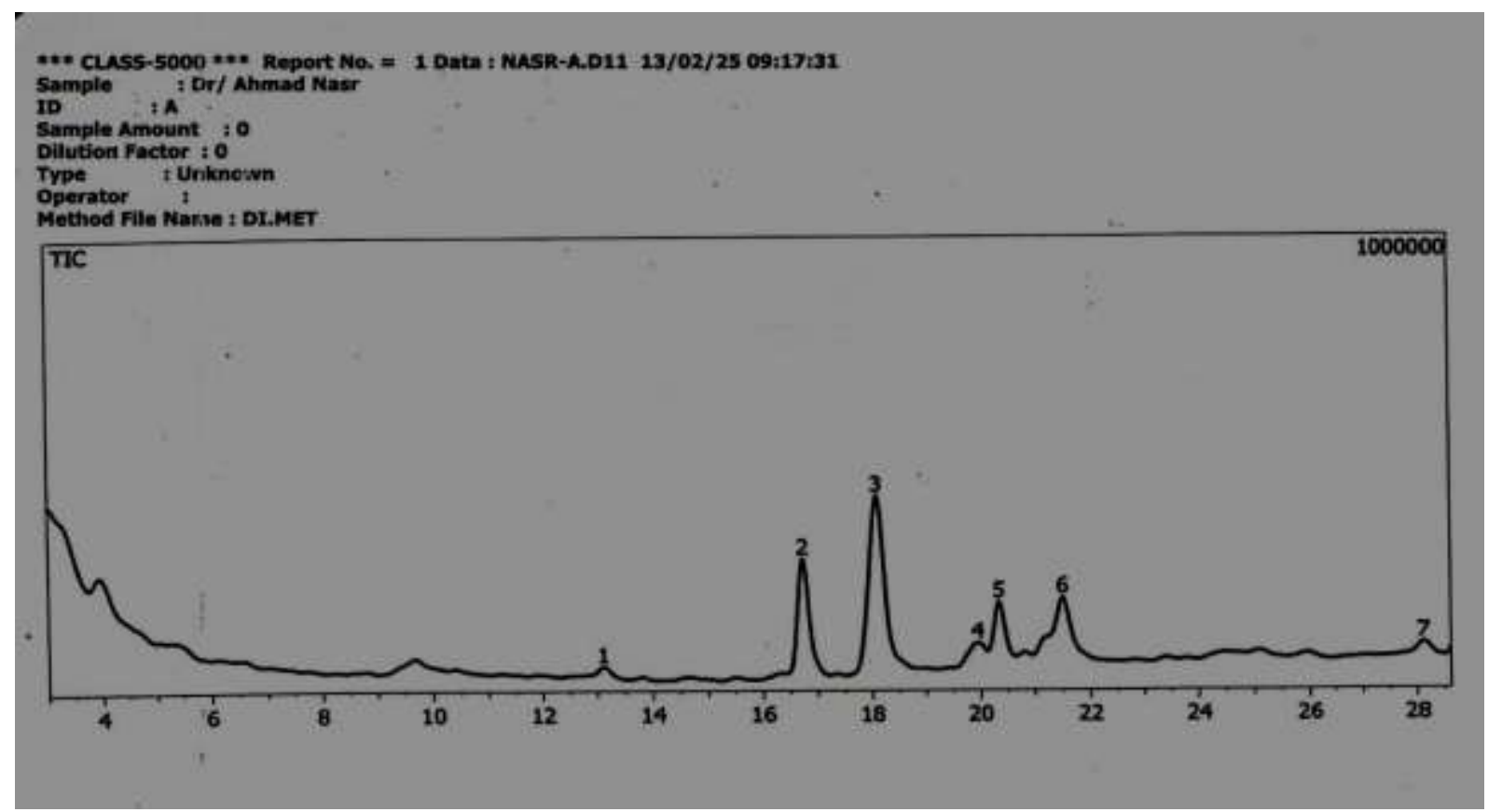

Fig (1): GLC analysis of lipodal matter in peanuts, Arachis hypogaea (A).

\#* CLASS-5000 *** Report No. $=1$ Data $:$ NASR-B.D02 13/02/25 09:17:31

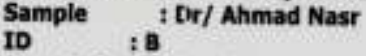

Sample Amount : 0

Dilution Factor : 0

Type : Uniknown

Operator :

Method File Narne : DI.MET

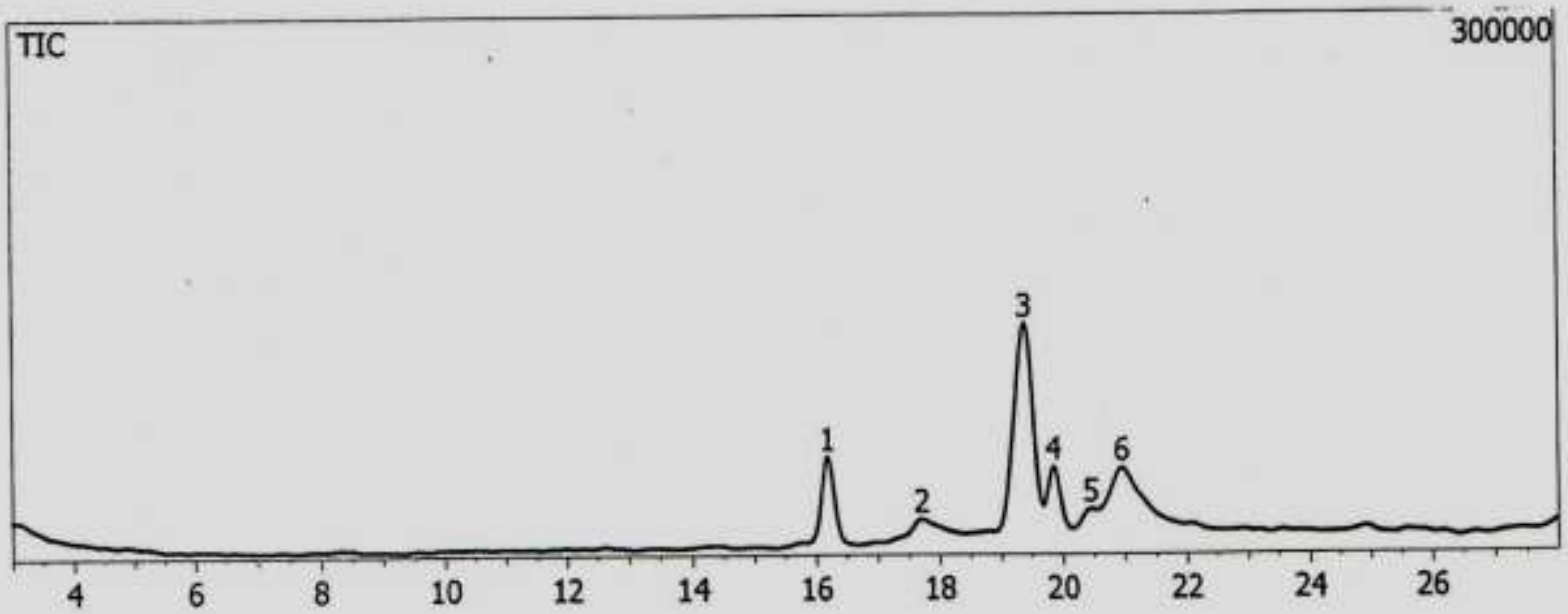

Fig (2): GLC analysis of lipodal matter in sesames, Sesamum Indicum (B). 


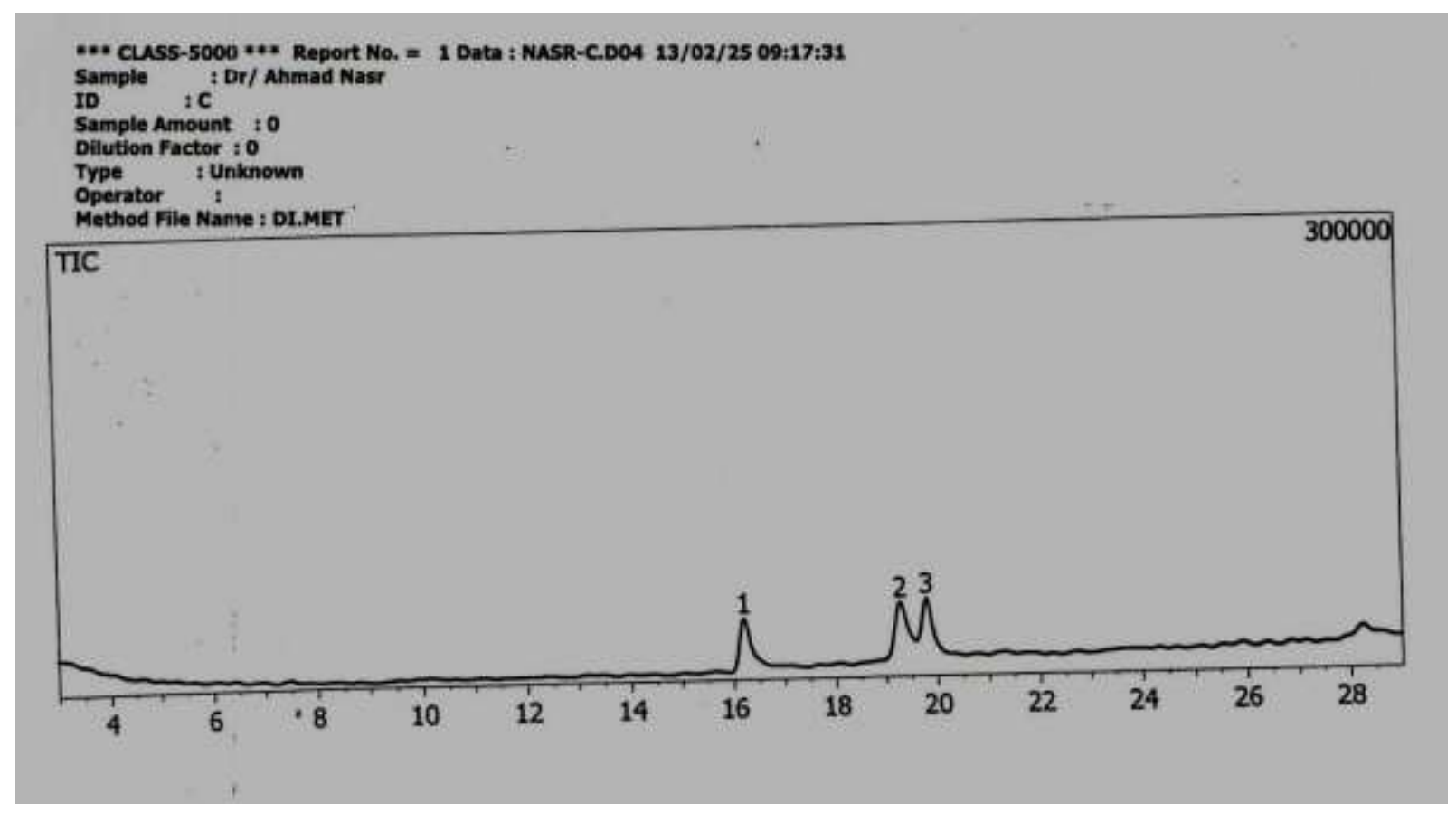

Fig (3): GLC analysis of lipodal matter in sun flower seeds, Helianthus Annuus (C).

\section{DISCUSSION}

Oleic, Laurie, Palmitic, Myristic, and Stearic Acids are long hydrocarbon chain carboxylic acids, known as fatty acids. They are usually produced by hydrolysis of common animal and vegetable fats and oils. Fatty acids are generally used as intermediates in the manufacture of their alkali salts, which are in turn used as emulsifiers, emollients, and lubricants in a variety of cosmetic creams, cakes, soaps, and pastes (Grundy, 1994).

Well over 1,000 different fatty acids are known which are natural components of fats, oils (triacylglycerols), and other related compounds (Gunstone \& Norris, 1983). These fatty acids can have different alkyl chain lengths (typically ten or more carbon atoms), 0-6 carboncarbon double bonds posessing cis- or trans-geometry, and can contain a variety of functional groups along the alkyl chain (Gunstone et al., 2007). Of these, there are approximately 20-25 fatty acids that occur widely in nature, are produced from commodity oils and fats, and find major use for food and nutrition applications with the remainder being used by the oleo chemical industry to produce soaps, detergents, personal care products, lubricants, paints, and more recently, biodiesel. Approximately 17 commodity fats and oils are obtained from various domesticated plants and animals.

The largest vegetable oil sources are the oilseed crops (soybean, rapeseed, sunflower, and cottonseed) grown in relatively temperate climates. Another major oil source are oilbearing trees (palm, coconut, and olive) grown in tropical or warm climates (O'Brien $\boldsymbol{e t}$ al., 2000). In 2009, the global production of fats and oils increased to 137.5 million tons with 21.2\% (29.3 million tons) used for non-food industrial purposes (Gunstone, 2011).

A number of earlier studies have utilized alternative lipid sources in feed formulations for Japanese and European sea bass at replacement levels of 50-60\%, and no influences in growth rates and feed conversion have been observed at the level (Du $\boldsymbol{e t} \boldsymbol{a l}$., 2002; Richard et al., 2006; Xue et al., 2006; Mourente and Bell, 2006), that mean when 
increase the percentages of lipid or fatty acid in tested diet lead to reduce the growth of tested animal, which similar with the present experiment by using very small amount as $0.05 \%$ in tested diet. Similar observation reported by $\mathbf{N g}$ et al. (2003) reported that increased dietary saturated fatty acid would lead to a reduction in the apparent digestibility of saturates fatty acid of African catfish.

In this study, when used the plant extract as antifungal and antibacterial to many fungi and bacteria which caused numerous disease in fresh water prawn $M$. rosenbergii also caused damage to diet as aflatoxin agent and give high resistance against bacterial and fungi infection. Which similar with some researchers also have reported that Chinese herbs could protect the fish or shrimp from pathogenic infection, increase immune factors such as blood lysozyme, the phagocytic activity, nitrogen monoxide content, phagocytic activity, and so on (Francis et al., 2002; Xie et al., 2008; Zhang et al., 2009) and indirectly increase growth of aquatic animal. Other observation reported by Liu et al., (2010) when study the effects of anthraquinone extracted from Rheum officinale Bail on growth, some non-specific immunite parameters, and disease resistance of $M$. rosenbergii which similarly all the results can be correlated with the resistance against bacterial infection to some degree, including the increase of haemolymph lysozyme activities, alkaline phosphatase activities, anti-oxidation abilities and the decrease of hepatic malondialdehyde content in the groups fed with $0.1-0.2 \%$ of anthraquinone extracts. The overdose of Chinese herbs might cause imbalance of bacterial populations in the intestine (Liu et al., 2004). ).

In this study, the results showed that the growth performance, feed and nutrient utilization and carcass composition of $M$. rosenbergii is significantly at $(\mathrm{P}<0.05)$ improved with addition $0.05 \%$ of sesames, Sesamum Indicum (B) extract in the diets compared to other plant extracts and control which followed with addition $0.05 \%$ of peanuts, Arachis Hypogaea (A) and mixture of them as $(\mathrm{AB})$ and $(\mathrm{ABC})$ extracts. Which similar with other results recorded that, dietary supplementation of Quillaja saponin increased the growth rate in common carp (Francis et al., 2002). Dietary supplementation of anthraquinone extracts in $0.1-0.2 \%$ elevated weight gain rate, feed conversion efficiency and reduced mortality rate of $M$. rosenbergii. However, overdose of supplements of anthraquinone extracts would be unfavorable to shrimp growth (Xie et al., 2008 and Liu $\boldsymbol{e t}$ al., 2010). in agreements with reports that Chinese herbs could promote growth of aquatic animals (Lin et al., 2006 and Jan and Wu et al., 2004).

About $80 \%$ of the fatty acid in beef is composed of palmitic (C16:0), stearic (C18:0), and oleic acid (C18:1). The remaining 20\% is distributed among 30 different fatty acids. Inference of the health effect of fatty acids is based on experimental diets enriched with selected fatty acids. Which act as mainly component of our studied extraction especially in Sesamum Indicum (B) and in Arachis Hypogaea (A) extracts but little (C) extract. Don et al., (2012). Investigated a dietary saturated, monounsaturated, and polyunsaturated fatty acids deposited to the same extent in adipose tissue of rabbits and results revealed that, positive correlations between the a mount of the five commonly consumed fatty acids (palmitic, stearic, oleic, linoleic, and linolenic acids) in the diet and their deposition into the adipose tissue were observed which fed with five different fats (linseed, rapeseed, cocoa butter, palm, and sun flower oils) to regain initial body weights.

Oleic acid (18:1 $\grave{\omega}-9)$ is the primary monounsaturated fatty acid in beef and accounts for about $33 \%$ of the fatty acid in beef. It is also found in rich amounts in olive, canola, and peanut oils. In present study (A) and (B) contain high amount of oleic acid (18:1 ڤ̀-9), while the best percentage in (B) extract as (47.14\%) and lowest in (A) extract as $(4.86 \%)$ and found in $(\mathrm{C})$ extract as $(37.23 \%)$ in good amount which explain the elevate the growth rate of extract 
$(\mathrm{ABC})$ and $(\mathrm{AC})$, that mean $(\mathrm{C})$ extract was good when combined in mixture with other extracts more than alone. Durand et al., (2013) reported that, endogenous synthesis cannot compensate for absence of dietary Oleic acid in rats. It is important to know whether an organism is able to synthesize all the oleic acid it needs. In several studies on the relative carcinogenicity of fatty acids or their ability to suppress the immune system, oleic acid was the fatty acids with the least negative effect (Grundy, 1994).

Palmitoleic acid (16:1 $\dot{\omega}-7)$ is a mono-unsaturated fatty acid is beneficial in reducing bad cholesterol (LDL) and it behaves like a saturated and not as a unsaturated fatty acid in its effect on LDL cholesterol (Nestel et al., 1994). It also reduces the fat deposition in blood vessels and reduces blood clot formation (Grundy, 1994). This fatty acid present only in (B) extract as (13.51\%), which lead to promote growth of fresh water prawn and other aquatic animals. Tohru et al., (2010). Studied the Effects of sesamin-supplemented dietary fat emulsions on the ex vivo production of lipopoly saccharide-induced prostanoids and tumor necrosis factor $\dot{\alpha}$ in rats and data indicate that in rats, tube feedings of diets containing sesamin exerted anti inflammatory effects that were augmented by concurrent consumption of linseed oil.

$\dot{\alpha}$-Linolenic acid $(18: 3 \dot{\omega}-3)$ is classified as a short-chain omega-3 fatty acid and is also found in nuts and seeds. $\dot{\alpha}$-Linolenic acid $(18: 3 \dot{\omega}-3)$ are major fatty acids of marine algae, fatty fish and fish oils. In present study the $\dot{\alpha}$-Linolenic acid $(18: 3 \dot{\omega}-3)$ found only in (B) extract as (22.19\%). However, other studies reported no evidence of alpha- linolenic acid having a positive effect on cardiovascular heart disease and increase in the blood and plasma levels in human (Renaud et al., 2002; Sanderson et al., 2002). Which agreements with our results that enhance the growth and prevent infection of bacteria and fungi in culture and noted also in survival rate percentage which highly increased with (B) extract as $(87.5 \%)$ compared with extract (C) as (72.5\%) and control as (66.25\%).

For many years linoleic acid (C18:2; omega-6) was thought to be the preferable fatty acid for the diet because it was considered to be the most effective cholesterol-lowering fatty acid. However, despite an increase in linoleic acid intake (from about $4 \%$ to $7 \%$ ), there has been a growing reservation about recommending its consumption, due to no proven long-term safety (Grundy, 1994). In present study the best percentage in (A) extract as $(17.15 \%)$ and lowest in (B) extract as (3.35\%) and not found in (C) extract, hence give reason about elevate the growth performance and energy content of $M$. rosebergii with diet contain (A) extract. Similar observation in humans, high supplemental intakes of linoleic fatty acids can lower good cholesterol concentration and may increase the risk for cholesterol gallstones. In addition, the presence of linoleic acid in bad cholesterol lipids makes them more prone to oxidation, which could promote atherosclerosis. Because of these detrimental effects, current recommendations have been moderated and now caution that intakes of this fatty acid should not exceed current concentrations (about $7 \%$ of total energy intake) (Grundy, 1994).

In present study water $\mathrm{pH}$ varied from 7.0 to 8.5 , temperature varied from 27 to $30^{\circ} \mathrm{C}$, dissolved oxygen values varied between 6 to $7.5 \mathrm{mg} / \mathrm{L}$, Salinity: it varied between 2.0 to $4 \%$, ammonia: it was varied from 0.01 to $0.08 \mathrm{mg} / \mathrm{l}$, Nitrate $\left(\mathrm{NO}_{3}\right)$ : it was fluctuated between 5 to $15 \mathrm{ppm}$ and Nitrite $\left(\mathrm{NO}_{2}\right)$ : it was varied from 0.01 to $0.09 \mathrm{ppm}$ during the experimental period, all of this water quality results located within the optimum water quality that used in nursery and husbandry of fresh water prawn $M$. rosenbergii, which agreements with results noted with (Armstrong et al., 1978 and Boyed and Zimmermann., 2000). 


\section{CONCLUSIONS}

In short, the results showed that the growth performance, feed and nutrient utilization and carcass composition of $M$. rosenbergii is significantly at $(\mathrm{P}<0.05)$ improved with addition $0.05 \%$ of sesames, Sesamum Indicum (B) extract in the diets compared to other plant extracts and control which followed with addition $0.05 \%$ of peanuts, Arachis Hypogaea (A) and mixture of them as $(\mathrm{AB})$ and $(\mathrm{ABC})$ extracts. So the supplement of $0.05 \%$ of sesames, Sesamum Indicum (B) extract can increase immune, protect freshwater prawn against the pathogenic infection, and promote the growth of prawns.

\section{ACKNOWLEDGMENTS}

The authors would like to express their gratitude to the Dr. Khalid A. El-Damhogy and Ateif A. A. El-Heila who responsible for Pharmacognosy Department, Faculty of Pharmacy, Al-Azhar University, Cairo for helping in the lab activities of collection and measurements also all the post graduate students of Pharmacognosy Department, Faculty of Pharmacy, AlAzhar University, Cairo, who somehow contributed to this study.

\section{REFERENCES}

AOAC (2000): Association of Official Analytical Chemists, Official methods of analysis, 17th Ed. Washington, DC., USA.

Armstrong, D.A., Chippendale, D., Knight, A.W., Colt, J.E., (1978): Interaction of ionized and un-ionized ammonia on short-term survival and growth of prawn larvae, Macrobrachium rosenbergii. Biol. Bull. 154, 15- 31.

Bearson, S., Bearson, B., Foster, J.W., (1997): Acid stress responses in enterobacteria. FEMS Microbiology Letter 147, 173-180.

Boyed, C. and Zimmermann, S. (2000): Grow-out systems-water quality and soil management. In M. B. New \& W. C. Valenti, Eds. Fresh water prawn culture :the farming of Macrobrachium rosenbergii, Pp.221-238. Oxford, England, Blackwell Science.

Castell and Tiews (1980): Report of the EIFAC, IUNS and ICES Working Group on the Standardization of Methodology in Fish Research. Hamburg, FRG, Germany, 2123 March. IFAC Tech. Pap. (3) 24.

Cherrington, C.A., Hinton, M., Pearson, G.R., Chopra, I., (1991): Short-chain organic acids at pH 5.0 kill Escherichia coli and Salmonella spp. without causing membrane perturbation. Journal of Applied Bacteriology 70, 161-165.

Defoirdt, T., Halet, D., Sorgeloos, P., Bossier, P., Verstraete, W., (2006): Short chain fatty acids protect gnotobiotic Artemia franciscana from pathogenic Vibrio campbellii. Aquaculture 261, 804-808.

De Man, J.G., (1879): On some species of the genus Palaemon Fabr. with descriptions of two new forms. Notes from the Royal Zoological Museum of the Netherlands at Leiden, 1, pp. 165-184. 
Diarra, S. S. and Usman, B. A. (2008): Performanceof laying hens fed graded levels of soaked sesame (Sesamum indicum) seed meal as a source of methionine. Inter. J. Poult. Sci., 7(4): 323-327.

Don S Lin, William E Connor, and Charles W Spenler (2012): Are dietary saturated, monounsaturated, and polyunsaturated fatty acids deposited to the same extent in adipose tissue of rabbits. Am J C/in Nuir 1993:58: 174-9. Printed in USA. (C) 1993 American Society for Clinical Nutrition.

Durand, Jean-Marie E. Bourre,3 Odile L. Dumont, Michel E. Cle' ment and Georges A. (2013): Endogenous Synthesis Cannot Compensate for Absence of Dietary Oleic Acid in Rats. INSERM U 26. Ho^ pital Fernand Widal, 75475 Paris cedex 10, France and *INRA NASA, 78350 Jouy en Josas, France.

Du, Z.Y., Liu, Y.J., Zhen, W.H., Tian, L.X., Liang, G.Y., (2002): The effects of three oil sources and two anti-fat liver factors on the growth, nutrient composition and serum biochemistry indexes of Lateolabrax japonicus. Journal of Fisheries of China 26, 542-550.

FAO, (Food and Agricultural Organization) (2002): Farming of Freshwater Prawns: A Manual for the culture of the giant river prawn (Macrobrachium rosenbergii). FAO Fisheries Technical Paper 428. Food and Agriculture Organization, Rome, Italy.

FAO, (2000): Aquaculture Production Statistics 1989-1998. FAO Fisheries Circular, vol. 815. FAO, Rome. Rev. 12.

Floch et al (1956): Folch, J. H.Less and G.H. Solana Stanley. 1956. A simple method for the isolation and quantification of total lipid from animal tissues. Journal of Biological Chemistry, 226: 497-509.

Francis, G., Makkar, H.P.S., Becker, K., (2002): Dietary supplementation with a Quillaja saponin mixture improves growth performance and metabolic efficiency in common carp (Cyprinus carpio L.). Aquaculture 203, 311-320.

Gobi, B.(1981): Tropical feeds. Food and Agricultural Organization of the United Nations, Rome.

Grundy S. M. 1994. Influence of stearic acid on cholesterol metabolism relative to other longchain fatty acids. Am. J. Clin. Nutr. 60 (Suppl):986S-90S.

Gunstone, F.D. (2011): Non-food uses of vegetable oils. Lipid Technol. Vol.23, pp. 24, ISSN $1863-5377$.

Gunstone, F.D., Harwood, J.L., \& Dijkstra, A.J. (Eds.) (2007): The Lipid Handbook with CDROM, Third Edition, CRC Press, ISBN 0-8496-9688-3, Boca Raton, Florida.

Gunstone, F.D. \& Norris, F. (1983): Lipids in Foods: Chemistry, Biochemistry and Technology, Pergamon Press, ISBN 0-08-025499-3, Oxford, England.

Harrison, K.E., (1990): The role of nutrition in maturation, reproduction and embryonic development of decapod crustaceans: a review. J. Shellfish Res. 9, 1-28.

Holder IA, Boyce ST (1994): Agar well diffusion assay testing of bacterial susceptibility to various antimicrobials in concentrations non-toxic for human cells in culture. Burns 20:426-429.

ISO (1979): International Standard Organization .Animal feeding stuffs determination of nitrogen content and calculation of crude protein content. Switzerland Method no 5983.1979. 
Jian $J$ and $W u$ Z. (2004): Influences of traditional Chinese medicine on non-specific immunity of Jian carp (Cyprinus carpio var. Jian). Fish Shellfish Immunol; 2:18591.

Kabir Chowdhury M.A., El-Haroun E.R., Goda A.M.A-S, Wafa M.A, and Salah El-Din S.A., (2007): Growth performance of post-larval freshwater prawn Macrobrachium rosenbergii (de Man 1879) at different dietary protein levels and feeding times. Aquaculture 2007, science for sustainable aquaculture, February, 2007, San Antonio Convention Center, San Antonio, Texas, USA, World Aquaculture Society Annual Meeting 2007.

Lim C. and Dominy, W. (1991): Utilization of plant proteins by warm water fish. In: Proceedings of the Aquaculture Feed Processing and Nutrition Workshop [Akiyama D.M., R.K.H. Tan (eds.)]. American Soybean Association, Singapore: pp.163-172.

Lin HZ, Li ZJ, Chen YQ, Zheng WH, Yang K. (2006): Effect of dietary traditional Chinese medicines on apparent digestibility coefficients of nutrients for white shrimp Litopenaeus vannamei, Boone. Aquaculture; 253:495-501.

Liu, H.B., Zhang, Y., Yang, Y.H., Lu, T.Y., Ye, J.D., (2004): Effects of five Chinese herb medicines as additive in feed on the growth and intestinal microflora in common carp (Cyprinus carpio). J. Dalian Fish. Univ. 1, 16-20 (In Chinese).

Liu Bo, Xianping Ge, Yanhui He b,1, Jun Xie, Pao Xu, Yijin He, Qunlan Zhou, Liangkun Pan, Ruli Chen, Bo Liu, Xianping Ge, Yanhui He, Jun Xie, Pao Xu , Yijin He, Qunlan Zhou, Liangkun Pan, Ruli Chen(2010): Effects of anthraquinones extracted from Rheum officinale Bail on the growth, non-specific immune response of Macrobrachium rosenbergii. Aquaculture 310 (2010) 13-19. journal homepage: www.elsevier.com/locate/aqua-online

Mariappan, P. and Balasundaram, C. (2004): Effect of shelters, Densities, and weight Groups on survival, growth and Limb loss in the fresh water prawn, Macrobrachium rosenbergii. Journal of Applied Aquaculture, 15: 51- 63.

Mourente, G., Bell, J.G.,( 2006): Partial replacement of dietary fish oil with blends of vegetable oils (rapeseed, linseed and palm oils) in diets for European sea bass (Dicentrarchus labrax L.) over a long term growth study: effects on muscle and liver fatty acid composition and effectiveness of a fish oil finishing diet. Comparative Biochemistry and Physiology 145B, 389-399.

Nahm,K.H. (2007): Efficient phosphorus utilization in poultry feeding to lessen the environmental impact of excreta. World's Poult. Sci., 63: 625-654.

Ng, W.K., Lim, P.K., Boey, P.L., (2003): Dietary lipid and palm oil source affects growth, fatty acid composition and muscle á-tocopherol concentration of African catfish, Clarias gariepinus. Aquaculture 215, 229-243.

NRC (National Research Council). (1993): Nutrient Requirements of Warm water Fishes and Shellfishes. National Academy of Science, Washington, DC, USA.

O'Brien, R., Farr, W., \& Wan, P. (Eds.). (2000): Introduction to Fats and Oils Technology (second edition), AOCS Press, ISBN 1-893997-13-8, Champaign, Illinois, USA.

Pena, D.G., R.G.L. Anguiano and J.J.M. Arredondo, (1992): Modification of the method 1 AOAC (CBmethod) for the detection of aflatoxins, Bull.Environ. Contam. Toxicol., 49: 485-489. 
Recker (1975): Ricker, W. E. (1975): Computation and interpretation of biological statistics of fish populations. Fish. Res. Board Can. Bull., 191, 1-382.

Renaud S., and Lanzmann-Petithory D. (2002): Dietary fats and coronary heart disease pathogenesis. Curr Atheroscloe. Rep. 4:419-424.

Richard, N., Mourente, G., Kaushik, S., Corraze, G., (2006): Replacement of a large portion of fish oil by vegetable oils does not affect lipogenesis, lipid transport and tissue lipid uptake in European seabass (Dicentrarchus labrax L.). Aquaculture 261, 1077-1087.

SAS (Statistical Analysis System) (1988): SAS / STAT user's guide release 6.03 edition. SAS Institute Inc. Cary, North Carolina, USA.

Sanderson P., Y. E. Finnegan, C. M. Williams, P. C. Calder, G. C. Burdge, S. A. Wootton, B. A. Griffin, D. J. Millward, N. C. Pegge and W. J. E. Bemelmans. (2002): UK food standarts agency $\alpha$-linolenic acid workshop report. Br. J. Nutr. 88:573-579.

Sun, C.Q., O'connor, C.J., Turner, S.J., Lewis, G.D., Stanley, R.A., Roberton, A.M., (1998): The effect of $\mathrm{pH}$ on the inhibition of bacterial growth by physiological concentrations of butyric acid: implications for neonates fed on suckled milk. Chemical-Biological Interactions 113, 117-131.

Teshima, S., (1972): Sterol metabolism. Mem. Fac. Fish., Kagoshima Univ. 21, 69-147.

Tohru Utsunomiya, Sambasiva R Chavali, W William Zhong, and R Armour Forse (2010): Effects of sesamin-supplemented dietary fat emulsions on the ex vivo production of lipopolysaccharide-induced prostanoids and tumor necrosis factor _ in rats. Am J Clin Nutr 2000;72:804-8. Printed in USA. (C) 2000 American Society for Clinical Nutrition.

Van Der Wielen, P., Biesterveld, S., Notermans, S., Hofstra, H., Urlings, B.A.P., Van Knapen, $\boldsymbol{F}$., (2000): Role of volatile fatty acids in development of the cecal microflora in broiler chickens during growth. Applied and Environmental Microbiology 66, 2536-2540.

Van Immerseel, F., Boyen, F., Gantois, I., Timbermont, L., Bohez, L., Pasmans, F., Haesebrouck, F., Ducatelle, R., (2005): Supplementation of coated butyric acid in the feed reduces colonization and shedding of Salmonella in poultry. Poultry Science 84, 1851-1856.

Van Immerseel, F., De Buck, J., Pasmans, F., Velge, P., Bottreau, E., Fievez, V., Haesebrouck, F., Ducatelle, R., (2003): Invasion of Salmonella enteritidis in avian intestinal epithelial cells in vitro is influenced by short-chain fatty acids. International Journal of Food Microbiology 85, 237-248.

Waldroup, A., Kaniawati, S., Mauromoustakos, A., (1995): Performance characteristics and microbiological aspects of broilers fed diets supplemented with organic acids. Journal of Food Protection 58, 482-489.

Wee, K.L. (1991): Use of non-conventional feedstuffs of plant origin as fish feeds- is it practical and economically feasible? In: Fish Nutrition Research in Asia. Proceedings of the Fourth Asian Fish Nutrition Workshop [De Silva S.S. (ed.)]. Asian Fisheries Society, Manila, Philippines: pp.13-32. 
Xie, J., Liu, B., Zhou, Q.L., Su, Y.T., He, Y.J., Pan, L.K., Ge, X.P., Xu, P., (2008): Effects of anthraquinones extract fromrhubarb $R$. officinale Bail on the crowding stress response and growth of common carp (Cyprinus carpio var. Jian). Aquaculture $281,5-11$.

Xue, M., Luo, L., Wu, X., Ren, Z., Gao, P., Yu, Y., Pearl, G., (2006): Effects of six alternative lipid sources on growth and tissue fatty acid composition in Japanese sea bass. Aquaculture 260, 206-214.

Zhang, G.B., Gong, S.Y., Yu, D.H., Yuan, H.W., (2009): Propolis and Herba epimedii extracts enhance the non-specific immune response and disease resistance of Chinese sucker, Myxocyprinus asiaticus. Fish Shellfish Immunol. 26, 467-472.

\section{تأثيـربعض الخلاصات النباتيـة على معدل نمـو مرحلة الطور ما بعد اليرقة لروبيان(جمبرى) المياة العذبة منة \\ خالد عبداللطيف الدمهوجى'، محمد احمد عبداللة زكى'، عاطف احمد عبدالحميد الحيلة"، عمرو محمد ناصف' ، احمد

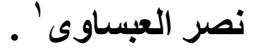

ا شعبـة علوم البحار و الأسماك ، قسـم علم الحيوان، كلية العلوم (بنين) ، جامعة الأز هر ، القاهرة.

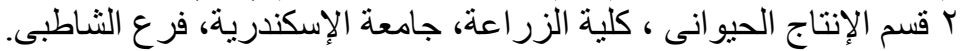

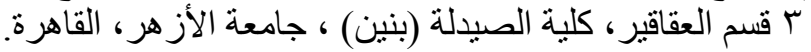

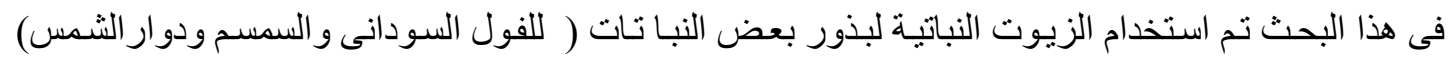

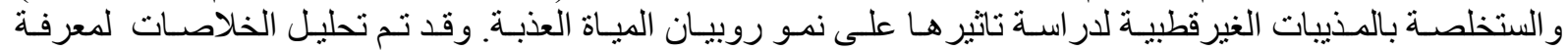

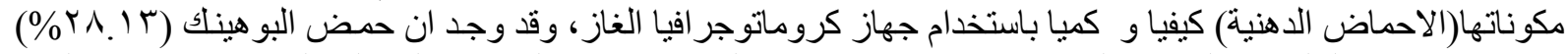

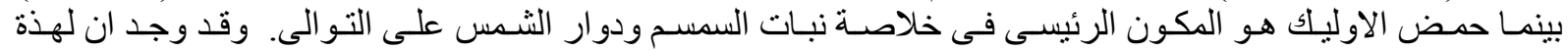

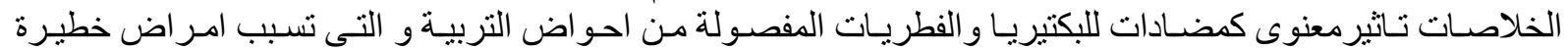
لروبيـان المـاء العذب (مستخلص بذور السمسم يليـة مستخلص الفول السودانى) و تتسبب في في خسائر فادحة في عمليـة

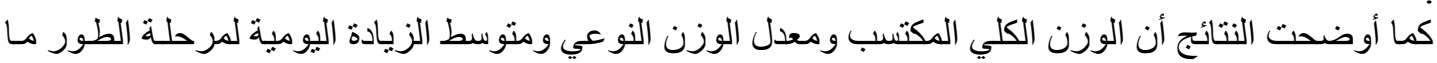

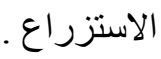

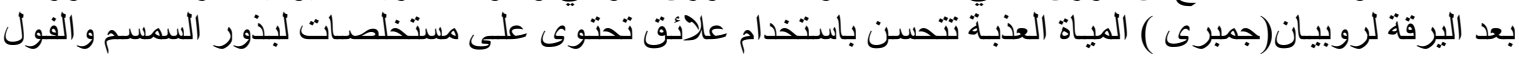

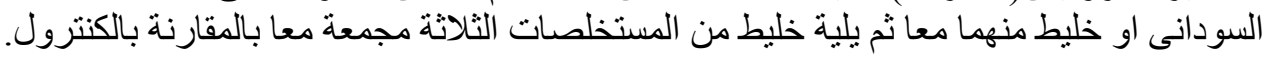

أوضحت النتائج الي أن أقل قيمة معدل إستفادة من البروتين و أقل قيمة لحم متكون في أجسام الأسماك المختبرة

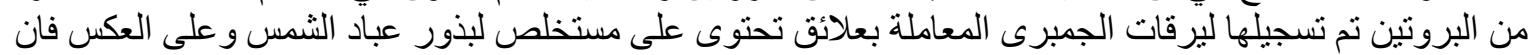

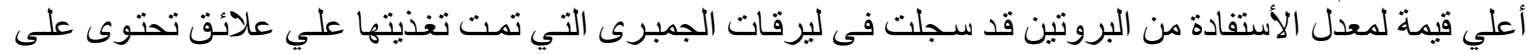

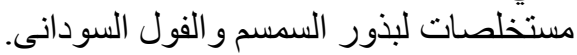

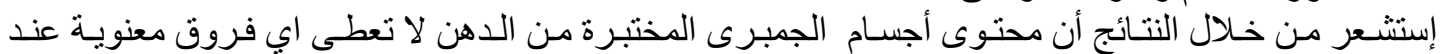

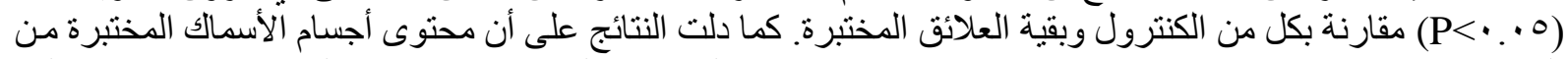

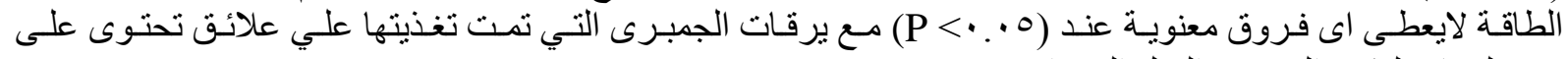
مستخلصات لبذور السمسم والفول السودانى. 